\title{
When Time Matters: Eastern Europe's Response to Chinese Competition
}

Citation for published version (APA):

Ciani, A., \& Mau, K. (2020). When Time Matters: Eastern Europe's Response to Chinese Competition. Maastricht University, Graduate School of Business and Economics. GSBE Research Memoranda No. 007 https://doi.org/10.26481/umagsb.20007

Document status and date:

Published: 03/03/2020

DOI:

10.26481/umagsb.20007

Document Version:

Publisher's PDF, also known as Version of record

\section{Please check the document version of this publication:}

- A submitted manuscript is the version of the article upon submission and before peer-review. There can be important differences between the submitted version and the official published version of record.

People interested in the research are advised to contact the author for the final version of the publication, or visit the DOI to the publisher's website.

- The final author version and the galley proof are versions of the publication after peer review.

- The final published version features the final layout of the paper including the volume, issue and page numbers.

Link to publication

\footnotetext{
General rights rights.

- You may freely distribute the URL identifying the publication in the public portal. please follow below link for the End User Agreement:

www.umlib.nl/taverne-license

Take down policy

If you believe that this document breaches copyright please contact us at:

repository@maastrichtuniversity.nl

providing details and we will investigate your claim.
}

Copyright and moral rights for the publications made accessible in the public portal are retained by the authors and/or other copyright owners and it is a condition of accessing publications that users recognise and abide by the legal requirements associated with these

- Users may download and print one copy of any publication from the public portal for the purpose of private study or research.

- You may not further distribute the material or use it for any profit-making activity or commercial gain

If the publication is distributed under the terms of Article $25 \mathrm{fa}$ of the Dutch Copyright Act, indicated by the "Taverne" license above, 


\section{Maastricht University}

Andrea Ciani, Karsten Mau

When Time Matters: Eastern Europe's Response to Chinese Competition

$\mathrm{RM} / 20 / 007$

\section{GSBE}

Maastricht University School of Business and Economics

Graduate School of Business and Economics

\section{P.O Box 616}

NL-6200 MD Maastricht

The Netherlands 


\title{
When Time Matters: Eastern Europe's Response to Chinese Competition*
}

\author{
Andrea Ciani ${ }^{\mathrm{a}}$ \\ Düsseldorf Institute \\ for Competition Economics \\ (DICE)
}

\author{
Karsten $\mathrm{Mau}^{\mathrm{b}}$ \\ Maastricht University \\ School of Business and Economics \\ (SBE)
}

February 27, 2020

\begin{abstract}
This paper presents evidence in support of a novel source of comparative advantage that arises from geographic proximity between trading partners and differential importance of timely delivery across industries (i.e. time-sensitivity). To test this channel, we investigate adjustments to Chinese export competition by a group of Eastern and Southeastern European (ESE) countries within EU15 destination-product markets. We rely on instrumental variables to extract exogenous variation in the expansion of Chinese export supply capacity across products and destinations. While finding sizable displacements effects materializing in terms of both export revenues and quantities, they appear to be about 50 percent smaller for time-sensitive exports. We further show that distance between trade partners co-determines this differential effect. Firm level results for a single ESE country support these findings. Geographic proximity seems to shield firms from external competition in specific activities.
\end{abstract}

JEL-Classification: F14, F15, F61, L25

Keywords: International competition, Geographic proximity, Time sensitivity, China, European integration, Regional production networks

${ }^{*}$ We would like to thank Davin Chor, Andrea Fracasso, Clemens Fuest, Andreas Lichter, Volodymyr Lugovskyy, Ariell Reshef, Peter Schott, Stefano Schiavo, Johannes Schuffels, and Jens Suedekum for their insightful comments and suggestions that helped us to improve this paper. We also thank participants at the ETSG-2018 conference in Warsaw, the EGI-2019 conference in Bari, the ISGEP-2019 workshop in Trento, the WGSC-2019 in Maastricht and at the EconPol Europe conference 2019 in Brussels for their discussions and questions. All errors are our own.

${ }^{\mathrm{a}}$ ciani@dice.uni-duesseldorf.de

bk.mau@maastrichtuniversity.nl 


\section{Introduction}

In a world where production processes and supply chains span across multiple countries and continents, timely delivery can be an important determinant of trade outcomes. Saving on time is equivalent to saving on costs when fast and reliable delivery allows firms to economize on their inventories. Short processing times can also provide access to markets with customized orders or generally less predictable demand fluctuations. Regarding its role in international trade, elapsing time is typically seen as a trade barrier (Hummels and Schaur, 2013).

This has implications for the market access prospects of exporters willing to ship to distant destinations. Conversely, and for the same reasons, time might shield certain firms from competitors that are unable to overcome this barrier. Whenever goods differ in their time-sensitivity, geographic proximity might endow a country with a source of comparative advantage that is distinct from conventional differences in factor endowments or technology. A supplier residing in closer geographic proximity to the customer would (all other things equal) be preferred over a more distant supplier, due to shorter delivery time. This simple prediction is conceptually related to Deardorff's (2014) notion of a local comparative advantage that arises in the presence of trade costs. To the best of our knowledge, however, this conjecture has not been empirically tested, despite evident differences in time-sensitivity across products and industries (Djankov et al., 2010; Hummels and Schaur, 2013).

In this paper, we test this prediction by focusing on the EU15 import market for manufacturing products. Specifically, we evaluate the performance of Eastern European exports within narrow EU15 destination-product markets and their response to intensifying Chinese competition during the late 1990s and early 2000s. Eastern European exporters are undoubtedly more proximate and more capable of timely delivery to the EU15 than China. To give an example: a container vessel travelling from the port of Guangzhou in China to the port of Rotterdam (via the Suez channel) has to bridge almost 18,000km. This takes almost three weeks, excluding export and import processing times at the port, document clearance times, and any other transport times between origin and final destination). ${ }^{1}$ Since most of the trade between China and the EU15 takes place via ocean shipping, Eastern European exporters might be able to compensate potential cost disadvantages with their ability to supply earlier, when time matters.

Our analysis relies on a disaggregated panel of exporter-importer-product level trade flows during the period 1997-2007. In order to investigate effects at the firm-level, we also rely on data from Bulgarian exporting firms for the period 2001-2006. Both periods extend

\footnotetext{
${ }^{1}$ Numbers are based on an average vessel speed of 20 knots, using calculations from sea-distances. org.
} 
over years where China experienced a substantial expansion of its exports. This allows us to exploit identification strategies that have been widely used in the empirical literature on Chinese competition (e.g. Autor et al., 2013; Utar and Torres Ruiz, 2013; Utar, 2014; Pierce and Schott, 2016). To distinguish products in terms of their time-sensitivity, we use the methodology from Hummels and Schaur (2013) and estimate the tariff equivalent of a markup customers are willing to pay for a one-day earlier delivery. Higher mark-ups according to this measure indicate higher time-sensitivity. We observe this measure at the HS 2-digit level.

We report two main findings. First, we find evidence of export competition between Chinese and Eastern European countries within narrow EU15 product-destination markets. Although both Eastern Europe and China increased their shares in EU15 manufacturing imports during the period of investigation, we can identify a 13 percent reduction in Eastern European export revenues due to China's expansion. Results from our Bulgarian firm-level sample suggest smaller displacement effects, overall (within firms), and a comparatively smaller impact on multi-destination exporters. While part of the difference with respect to the product-level findings might be attributed to differences in the data structure, we also find that Eastern European countries with a higher real GDP per capita, lower price levels, and higher FDI inflows (as percent of GDP) are generally less affected. Our analysis suggests that the last two attributes appear to be relevant for Bulgaria, for which we also observe differential unit value responses to Chinese competition. They partly explain the modest reductions in export revenues.

Our second finding is that exports in time-sensitive industries are substantially less affected by Chinese competition. Depending on our measure and specification, we report 40-60 percent smaller displacement effects. This relative resilience is distinct from other product and industry characteristics, such as skill-intensity or Nunn's (2007) measure of contracting intensity. Not surprisingly, time-sensitive goods appear to be partly (but not fully) represented by intermediate inputs which are typically traded in international supply chains and production networks. In terms of its magnitude, the estimated relative resilience in time-sensitive industries is comparable to that of relatively skill-intensive products. We also provide evidence in support of a relationship between geographic proximity and local comparative advantage in time-sensitive industries. Placebo regressions with a sample of distant low-wage Asian exporters reveal that differential impacts of Chinese competition in time-sensitive industries are either small or statistically insignificant (and with the wrong sign). Moreover, and further in line with the idea that geographic proximity co-determines timely delivery, we show that relative resilience in time-sensitive industries reveals mainly for short-distance trade between Eastern Europe and EU15 destinations. 
To our knowledge, this study is the first connecting two strands of the empirical trade literature, which so far developed independently. Our first finding contributes to the abundant body of research on the impact of China's economic expansion during the early 2000s. ${ }^{2}$ Despite its abundance, however, we are the first to quantify China's impact on Eastern European exports. ${ }^{3}$ The reduction in their export revenues is in line with conjectures of Dauth et al. (2014), who emphasize that German importers perceive Chinese, Eastern (and other South) European product varieties as substitutes. Our findings support this hypothesis and generalize it to the entire EU15. Quantitatively, our estimates suggest similar, yet, somewhat lower displacement effects than Utar and Torres Ruiz (2013) document for Mexican maquiladora plants facing Chinese competition in the US during the same period. In contrast to their study, we observe a much wider range of exporting and importing countries at a more disaggregated level. By observing 6-digit products instead of sectors, we are able to measure the incidence of competition more precisely. Moreover, by observing differential intensification of competition across destination markets, we can confirm that our results are not driven by an omitted variable bias stemming from general product-level dynamics. This is a key advantage also with respect to several other studies, which typically identify Chinese competition solely at the product or industry level.

Our second contribution relates to the literature highlighting the role of time in international trade (e.g. Nordås et al., 2006; Djankov et al., 2010; Hummels and Schaur, 2013). So far its role in the context of international competition has been neglected in empirical applications. ${ }^{4}$ We use the case of China's economic expansion to connect it to this literature and to investigate its implications for the patterns of trade. Our results suggest that timely delivery can shield countries (or firms) from external competition in a similar way as skill-, technology- or quality-upgrading do (e.g. Bernard et al., 2006; Khandelwal, 2010). Regional economic integration through trade-facilitating infrastructure and legal provisions might therefore be an appropriate response to external competition and enable firms to specialize and attain comparative advantage in time-sensitive activities. At the same time, however, its local nature denotes an important limitation. While it prevents other competitors from entering the existing market it will also limit the potential of accessing new distant

\footnotetext{
${ }^{2}$ This literature can be divided into studies focusing on Chinese import competition in the US (e.g. Autor et al., 2013, 2014; Pierce and Schott, 2016) and Europe (e.g. Bugamelli et al., 2015; Bloom et al., 2016; Dauth et al., 2014; Utar, 2014, 2018), and studies investigating displacement effects of China's expansion on other countries' exports (e.g. Adams et al., 2006; Eichengreen et al., 2007; Greenaway et al., 2008; Amann et al., 2009; Hanson and Robertson, 2010; Utar and Torres Ruiz, 2013; Flückiger and Ludwig, 2015; Mattoo et al., 2017; Mau, 2019).

${ }^{3}$ Silgoner et al. (2015) is the only study we are aware of that has sought to evaluate China's impact on exports of Eastern European countries. They rely on a descriptive decomposition analysis, which makes it difficult to compare their findings with ours or the related literature cited above.

${ }^{4}$ An exception which presents mainly anecdotal evidence is Evans and Harrigan (2005).
} 
markets for those exporters specialized in time-sensitive products.

Our paper unfolds as follows. Section 2 presents our data and some descriptive statistics that suggest a differential performance of trade in time-sensitive industries. Section 3 focuses on the empirical approach and discusses our identification strategy for evaluating the causal impact of China on ESE exports. Section 4 presents our main findings and robustness checks for both general export competition and for differential adjustments in time-sensitive industries. Additional results and further margins of adjustments are analysed in Section 5, while Section 6 concludes.

\section{Data and descriptive statistics}

International trade data. We use product-level information on bilateral trade in manufacturing goods between ESE exporters and EU15 destinations. The data comes from the CEPII BACI database, where flows are disaggregated at the 6-digit HS level and reported in terms of their free-on-board (f.o.b.) value, as well as their quantity (in kilograms). Since we compile our sample from two editions of the BACI data, we harmonize HS6 product codes using correspondence tables from the United Nations Statistics Division (UNSD). Our sample of exporting economies is comprised of 16 ESE countries. ${ }^{5}$ On the importer side, we distinguish 14 destination markets that constitute the EU15 (Belgium and Luxembourg appear as a single destination in the data). Overall, our sample spans the period from 1997 to 2007 .

We also use firm-level customs data for Bulgaria's manufacturing goods exports to the EU15. Firm-level information allows us to explore further dimensions of the impact of Chinese competition that cannot be observed in the product-level trade data. The data comes from the Exporter Dynamics Database (EDD), compiled by the World Bank (Fernandes et al., 2016), and spans the period 2001-2006. ${ }^{6}$ As in our product-level data set, we observe bilateral export values and quantities at the HS6 product level. An important difference is that the product-level data does not report shipments with a value below 1,000 USD, whereas the Bulgarian firm-level data includes such smaller amounts. We will account for this discrepancy in the sampling by employing quantity-weighted OLS specifications.

In Table 1, Panel A, we present some features of our product-level trade data. Exports

\footnotetext{
${ }^{5}$ They can be further divided into Eastern European (EEC) and Southeast European (SEE) countries. EEC are: Czech Republic, Estonia, Hungary, Latvia, Lithuania, Poland, Slovak Republic and Slovenia. SEE refers to Albania, Bosnia and Herzegovina, Bulgaria, Croatia, Northern Macedonia, Romania, SerbiaMontenegro, and Turkey.

${ }^{6}$ Customs data at the firm-product-destination level is confidentially available from the EDD for a limited group of countries.
} 
Table 1: Descriptive statistics of product- and firm-level trade data

\begin{tabular}{|c|c|c|c|c|c|c|}
\hline \multicolumn{7}{|c|}{ Panel A: ESE exporting countries, 1997-2007 } \\
\hline \multirow[t]{2}{*}{ Observation in sample } & \multicolumn{3}{|c|}{ First year (1997) } & \multicolumn{3}{|c|}{ Last year (2007) } \\
\hline & Mean & Median & Std. Dev. & Mean & Median & Std. Dev \\
\hline EU15 share in total exports (\%) & 56.7 & 56.6 & 14.1 & 55.3 & 55.4 & 11.6 \\
\hline Total \# of shipments to EU15 & 7,467 & 5,988 & 5,621 & 10,369 & 8,074 & 5,621 \\
\hline \# HS6 products shipped & 1,923 & 2,019 & 894 & 2,134 & 2,195 & 772 \\
\hline \# HS6 per destination & 856 & 847 & 479 & 1,012 & 974 & 510 \\
\hline \# Destinations per HS6 & 5.3 & 5.4 & 1.9 & 6.7 & 7.0 & 2.2 \\
\hline \multicolumn{7}{|l|}{ Panel B: Bulgarian firms, 2001-2006 } \\
\hline \multirow[t]{2}{*}{ Observation in sample } & \multicolumn{3}{|c|}{ First year (2001) } & \multicolumn{3}{|c|}{ Last year (2006) } \\
\hline & Mean & Median & Std. Dev. & Mean & Median & Std. Dev \\
\hline EU15 share in total exports (\%) & 81.19 & 99.70 & 30.63 & 78.62 & 98.28 & 31.72 \\
\hline Total \# of shipments to EU15 & 34.32 & 18 & 46.69 & 39.86 & 21 & 58.00 \\
\hline \# HS6 products shipped & 33.12 & 18 & 43.70 & 38.32 & 21 & 54.26 \\
\hline \# HS6 per destination & 18.33 & 10 & 22.31 & 20.58 & 10 & 29.23 \\
\hline \# Destinations per HS6 & 1.56 & 1 & 1.35 & 1.73 & 1 & 1.72 \\
\hline
\end{tabular}

Note: Panel A reports statistics for product-level trade data, based on the final estimation sample covering 16 exporting countries, 14 destinations, and 3,903 HS6 manufacturing products. Number of observations: 1,628,298; cross-sections (exporter-importer-HS6): 258,569; average years per cross-section: 6.3. Panel B reports statistics for Bulgarian firm-level trade data. Number of observations: 268,822; cross-sections (firmimporter-HS6): 162,554; average years per cross-section: 1.65 .

into the EU15 account for a stable 55 percent of ESE countries' total manufacturing export revenues and an average country roughly reports 7,500 to 10,400 shipments per year. However, variation across exporters is substantial: the least active ESE exporter (Albania) reports 1,046-1,382 shipments per year, while the most active one (Czech Republic) counts 18,366-22,993 annual shipments. The geographic diffusion of exports is limited: the average ESE exporter ships its average product to at most half of the EU15 destination markets (5-7 out of 14). Panel B shows corresponding statistics for our sample of Bulgarian firms, of which we observe 8,916 units on average per year. For the vast majority of firms EU15 markets are the main, if not the only export destination. However, comparing mean and median numbers for the EU15 share in revenues we note that some firms are substantially more diversified. Similar heterogeneity can be observed in the remaining categories. The average Bulgarian exporter reports between 34 and 39 shipments per year in which it sells between 33 and 38 different products. At the intensive firm-product margin, we note that the 
average product is exported to only 1-2 destinations. Overall, our firm-level sample displays a majority of highly specialized exporters and a relatively small number of highly diversified firms.

Time-sensitive industries. Our main objective is to analyze whether ESE exports enjoy a comparative advantage in time-sensitive trade with the EU15. To detect this advantage, we rely on a measure that indicates the industry-specific elasticity of demand with respect to a change shipping times. Focusing on this dimension is in line with empirical evidence on the trade-response to delays in shipment, which suggests that timely delivery matters more in some sectors than in others (Djankov et al., 2010). To obtain this measure we rely on the data and methodology of Hummels and Schaur (2013) and estimate the HS2-industry specific mark-up importers are willing to pay for a one day earlier delivery. Specifically, the estimation is based on a transport-mode choice model in which changes in shipping costs are exploited to estimate the relative demand for (fast) imports via air cargo versus (slow) imports via ocean shipment. ${ }^{7}$

We argue that measuring time-sensitivity in this way has two important advantages. First, since the measure is obtained from estimating a structural import demand equation, we can identify and control for potentially confounding factors at an early stage. This includes, for example, general exporter, distance, or price effects on the import demand. In doing so, we also avoid subjective judgements about the time-sensitivity of particular goods, which would be based on the description of the HS6 product codes. A second advantage is that our obtained indicator is based on US import data. This avoids potential measurement errors stemming from the endogeneity of transport mode choices that are related to importer-specific characteristics. One caveat, however, arises from imprecisely estimated time-sensitivity parameters. To address this, we consider two versions of this measure: (i) a simple (i.e. broad) measure, based solely on the magnitude of the point estimate; and (ii) an adjusted (i.e. strict) measure, where we set time-sensitivity equal to zero in HS2 sectors where the point estimate did not pass the 10 percent significance threshold. ${ }^{8}$

In Figure 1, we use the strict classification to see how ESE exports performed in timesensitive versus time-insensitive industries. Panel (a) shows that exports in the latter group expanded slower throughout our sample period. If we distinguish further between products

\footnotetext{
${ }^{7}$ The underlying model as well as the empirical approach is explained in detail in Appendix B.

${ }^{8}$ We report the respective frequency distributions of these two measures in Figure B1. Table B1 presents some specific examples of time-sensitive industries, using the strict measure. Four of the five most timesensitive industries belong to the chemical and allied industries. The fifth industry is motor vehicles and parts and accessories thereof. The five least time-sensitive industries are: (i) explosives and pyrotechnic products; (ii) wood pulp and recovered paper; (iii) raw hides and skins; (iv) pearls and precious stones or metals; (v) silk.
} 
Figure 1: ESE exports and Chinese expansion in time-sensitive vs. time-insensitive industries

(a) ESE export revenues

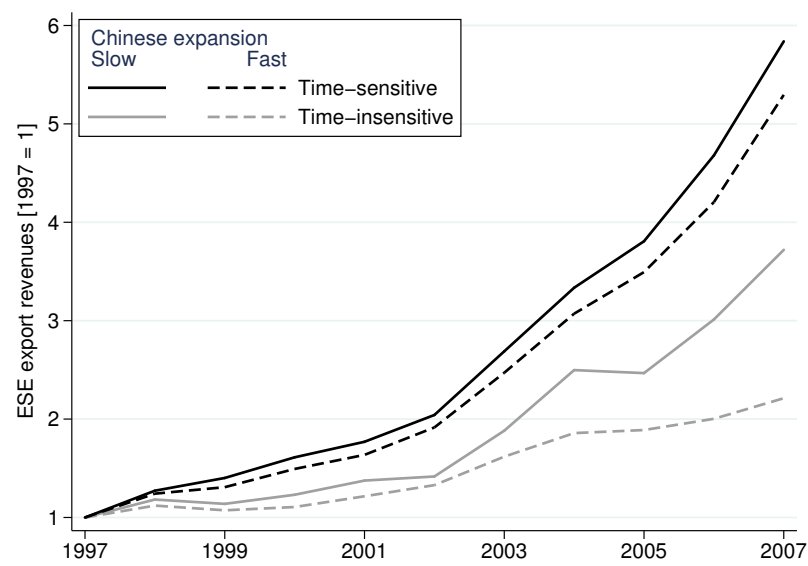

(b) Time-sensitive vs Time-insensitive

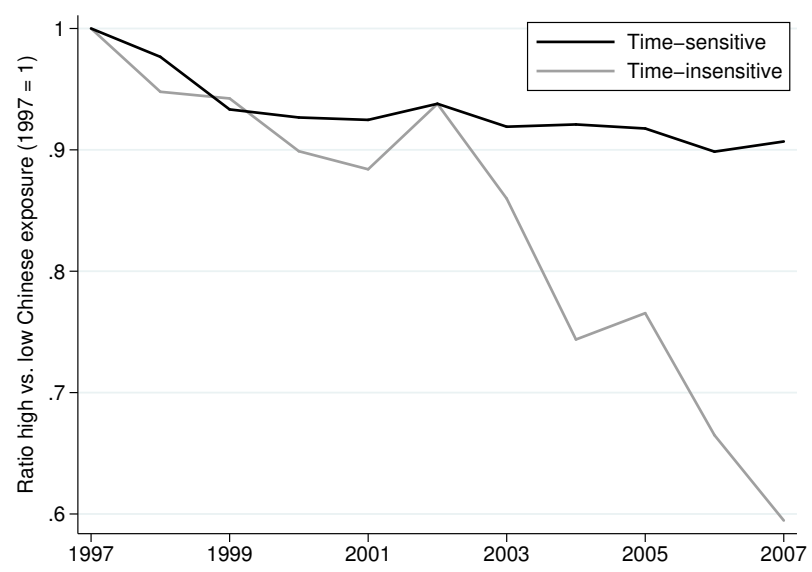

Note: Authors' calculations based on the strict measure of time-sensitivity. Time-sensitive denotes those sectors reporting time sensitivity above median. Panel (a) denotes aggregate export revenues in respective groups, relative to base year (1997). Panel (b) displays the ratio of ESE exports in fast-versus-slow expansion sectors, normalized to base year (1997). Chinese expansion is measured as average annual change in import market shares over the sample period. Fast (slow) expansion denotes HS6 products with above (below) median Chinese expansion within respective time-sensitivity group.

where China expanded fast and slow, within each industry group, we see that potential displacement effects appear larger in the time-insensitive industries. This becomes evident in Panel (b), which displays the ratio of the dashed over solid lines from Panel (a). ESE exports seem to be relatively more resilient to Chinese competition in time-sensitive industries, which lends indicative support to the core hypothesis of this paper. In the following section we describe our empirical model which we employ to evaluate the impact of Chinese competition on ESE exports.

\section{Empirical approach}

\subsection{Empirical baseline specifications}

For our product-level data, we set up a linear panel regression model of the following form:

$$
\ln Y_{i j k t}=\alpha+\beta C h i n a_{j k t}+\gamma \ln M_{j k t}+\mu_{i j k}+\mu_{i j t}+\nu_{i j k t} .
$$


The dependent variable, $\ln Y_{i j k t}$, measures the (log) value of shipments from ESE country $i$ to EU15 importer $j$, in HS6 product $k$ and year $t$. On the right hand side we include our main variable of interest, $C_{i n a_{j k t}}$, which measures China's expansion into the EU15 by its import market share in the respective product-destination. In order to account for potential confounding factors, we control for the evolution import demand at the destination-product level, $\ln M_{j k t}$, as well as aggregate demand and supply shifters using two set of fixed effects. Importer-exporter-time fixed effects, $\mu_{i j t}$, control for aggregate time-varying demand and supply shifters (such as business cycle dynamics, bilateral agreements and trade costs, or other country-pair specific factors). Exporter-importer-product fixed effects, $\mu_{i j k}$, capture time-invariant, product-specific demand and supply shifters (such as preferences, relative supply capacities, or persistent non-political trade barriers between two trading partners).$^{9}$ The last term on the right-hand side of Equation (1), $\nu_{i j k t}$, denotes an independent and identically distributed (i.i.d.) error term.

For our firm-level sample we adopt the analogous baseline specification:

$$
\ln Y_{f j k t}=\alpha+\beta C h i n a_{j k t}+\gamma \ln M_{j k t}+\delta \mathbf{X}_{f t}+\mu_{f}+\mu_{j k}+\mu_{j t}+\nu_{f j k t} .
$$

The key difference with respect to the product-level specification is that the exporting country's subscript $i$ becomes redundant, so that fixed effects $\mu_{j k}$ and $\mu_{j t}$ remain destinationproduct and destination-time specific. The new firm-level dimension $f$ is observed in the dependent variable, so that we augment our previous model with a full set of firm fixed effects, $\mu_{f}$, and time-varying firm-level controls, $\mathbf{X}_{f t} \cdot{ }^{10}$ Since in both our specifications the main coefficient of interest is $\beta$, we consider the dimensions of its associated variable and adjust standard errors for clustering at the destination-product level (Moulton, 1990).

\footnotetext{
${ }^{9}$ Our baseline specification is in line with gravity models where importers devote a constant fraction of their expenditures on foreign varieties and where China's expansion has an impact on the price-level of imports (e.g. Hanson and Robertson, 2010). In our robustness checks we show that including additional fixed effects barely alters our main qualitative and quantitative findings.

${ }^{10}$ As we have shown in Table 1, Bulgarian exporters appear to be rather specialized and typically export their goods to only one destination. Interacting firm fixed effects with an additional dimension would result in a substantial loss of both variation and actual observations in our data. Besides this technical restriction, we highlight that our firm-level specification is similar to Utar and Torres Ruiz (2013), who also employ individual plant fixed effect. Firm-level control variables will be explained in detail below and capture broadly firms' overall exporting experience as well as their overall size.
} 


\subsection{Measurement and identification}

We seek to capture Chinese competition by measuring its dominance within destinationproduct markets via the import market penetration rate: $C h i n a_{j k t}=M_{j k t}^{C N} / M_{j k t} .{ }^{11}$ Such a measure poses some challenges to identification, as OLS estimates will inform about correlations but not about causation. Indeed, it is possible that (i) causality runs from ESE exports to China's market shares or (ii) that there exists no causal relationship at all. The latter case includes the possibility of spurious correlation which, depending on the actual source of the observed correlation, can have different implications on the direction of the bias in the OLS coefficient. We discuss a number of plausible scenarios in Appendix A.

To address such concerns, the empirical literature is fairly consistent. Autor et al. (2013) and Utar and Torres Ruiz (2013) were among the first to employ an instrumental variable approach following Bartik (1991) in this context. It rests on the assumption that variation in Chinese expansion in market $j$ that can be jointly observed in similar destinations $n \neq j$ reflects actual changes in Chinese supply capacities, while eliminating variation arising from confounding factors. We select a group of high-income countries to reflect $n$ : Australia, Canada, New Zealand, Norway, and Switzerland. By focusing on relatively small highincome markets, with distance from China comparable to our EU15 destinations, we attempt to rule out that preference shifts in an individual destination or regional production networks determine our predictions on China's expansion. ${ }^{12}$

Note that in the context of our study observing China's product-market expansion in destinations $n$ is not enough, because it does not inform us about the extent to which it materializes across the different EU15 destinations. We therefore employ an augmented version of this instrument by assigning destination-specific weights to the import market penetrations rates observed in $n$ :

$$
\text { China }_{j k t}^{I V} \equiv\left(\text { China }_{k t} \times w_{j}\right)=\underbrace{\left(\frac{\sum_{n} M_{n k t}^{C N}}{\sum_{n} M_{n k t}}\right)}_{\begin{array}{c}
\text { product-year } \\
\text { variation }
\end{array}} \times \underbrace{w_{j}}_{\begin{array}{c}
\text { destination } \\
\text { variation }
\end{array}}
$$

\footnotetext{
${ }^{11}$ Overall market penetration is deemed to be more appropriate mainly in studies on the domestic responses to increasing import competition (e.g. Bernard et al., 2006; Autor et al., 2013, 2014; Dauth et al., 2014; Bugamelli et al., 2015). The unavailability of product-level data on domestic production prevents us from computing this measure at the HS6-product level. Indeed, studies employing this measure typically rely on aggregate sector-level data. Since we attempt to evaluate competition effects between countries exporting to the same third market, we are confident that import market shares are an appropriate measure for the purposes of our analysis.

${ }^{12}$ Preference shifts in a large destination market could have implications for China's multilateral trade performance (e.g. Mau, 2017). Moreover, high-income markets in relatively close proximity to China could lead to less precise predictions of Chinese competitiveness, if trade with these countries reflects shipments within regional production networks. See Appendix A for further discussion of this approach.
} 
To measure $w_{j}$, we exploit information on Hong Kong re-exports for the years 1999-2001 and compute $j$ 's fraction in its total re-exports to the EU15. We motivate this approach by noting that, prior to its WTO entry, China exported many of its goods via Hong Kong. Since this entailed additional surcharges (Feenstra and Hanson, 2004), improved market access provisions after WTO entry may have enabled Chinese exporters to avoid these surcharges and instead ship goods directly to the final destination. Such an adjustment would imply that Chinese exports expanded relatively faster in destinations where Hong Kong re-exports were larger. ${ }^{13}$

Our main instrument for China's expansion thus represents an interaction of the timevarying, product-specific import market penetration in other destinations, China $a_{k t}$, with the relative probability of destination $j$ to be entered by Chinese exports, $w_{j}$. By adding $w_{j}$ we generate a novel dimension of variation in competition intensity, which complements conventional identification via product-level changes in supply capacity. This enables us to fully exploit the information in our data and to perform additional robustness checks that have typically not been feasible in previous studies.

\section{Results}

\subsection{Displacement of exports through Chinese competition}

Product-level estimation. Table 2 conveys a clear message regarding the relationship between China's expansion into EU15 destination-product markets and ESE countries' export revenues. The first column displays our OLS results and suggests a negative relationship. Using the average expansion of China observed during our sample period, i.e. 5.47 percentage points, this implies a reduction by $5.47 \times 1.222 \approx 6.8$ percent between 1997 and 2007. Column (2) reports the results for our IV specification. The estimated coefficient is larger in absolute terms and suggests a reduction of ESE export revenues by 12.8 percent. This number is close to the displacement effect Utar and Torres Ruiz (2013) calculate for Mexican maquiladora plants selling to the US during the period 1990-2006. ${ }^{14}$ In the lower panel of Table 2, we report the main coefficients of interest obtained at the first stage of the IV estimation. In column (2) the coefficient shows the expected sign and test statistics sup-

\footnotetext{
${ }^{13}$ Hong Kong has been a GATT/WTO member since 1986 and maintained this status after formally becoming part of China in July 1997. Evidence in support of our suggested mechanism is provided in Figure A1, showing that Hong Kong's share in China's total transport services imports dropped persistently after 2002. Figure A2 presents the distribution of our destination-specific weight $w_{j}$.

${ }^{14}$ In their preferred specification, they report estimates that imply a reduction by about 18 percent during their sample period, in which China's market share increased by about 7 percentage points. Assuming the same expansion in our sample, we would obtain a reduction in ESE exports by 16.4 percent.
} 
port the predictive power of the instrument. In Table A1, we present results of a number of robustness checks in which we employ alternative clustering structures for the computation of our standard errors as well as additional sets of fixed effects. Our IV point estimates are remarkably robust, ranging between -2.024 and -2.343 across the different specifications.

Table 2: China's impact on ESE export values, product-level estimates, 1997-2007

\begin{tabular}{|c|c|c|c|c|c|c|}
\hline \multirow[b]{3}{*}{ Dep. var.: log export revenue } & $\overline{(1)}$ & $\overline{(2)}$ & 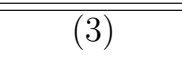 & $(4)$ & (5) & 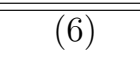 \\
\hline & \multicolumn{2}{|c|}{$\begin{array}{c}\text { Baseline } \\
\text { specification }\end{array}$} & \multicolumn{2}{|c|}{$\begin{array}{l}\text { Alternative IV: } \\
\text { US PNTR }\end{array}$} & \multicolumn{2}{|c|}{$\begin{array}{l}\text { Alternative IV: } \\
\text { MFA Quotas }\end{array}$} \\
\hline & OLS & 2SLS & Red. form & 2SLS & Red. form & 2SLS \\
\hline \multicolumn{7}{|c|}{ Main results: OLS and second stage } \\
\hline China $\left(s_{j k t}^{C N}\right)$ & $\begin{array}{c}-1.222^{* *} \\
(0.036)\end{array}$ & $\begin{array}{c}-2.343^{* *} \\
(0.158)\end{array}$ & & $\begin{array}{c}-2.807^{* *} \\
(0.398)\end{array}$ & & $\begin{array}{c}-2.648^{* *} \\
(0.314)\end{array}$ \\
\hline US PNTR & & & $\begin{array}{c}-1.119^{* *} \\
(0.167)\end{array}$ & & & \\
\hline MFA Quota fill rate & & & & & $\begin{array}{c}-1.161^{* *} \\
(0.126)\end{array}$ & \\
\hline Import demand & $\begin{array}{l}0.569^{* *} \\
(0.006)\end{array}$ & $\begin{array}{l}0.576^{* *} \\
(0.006)\end{array}$ & $\begin{array}{l}0.560^{* *} \\
(0.006)\end{array}$ & $\begin{array}{l}0.579^{* *} \\
(0.007)\end{array}$ & $\begin{array}{l}0.530^{* *} \\
(0.010)\end{array}$ & $\begin{array}{l}0.578^{* *} \\
(0.012)\end{array}$ \\
\hline First stage results for $s_{j k t}^{C N}$ & & Baseline & & US PNTR & & MFA \\
\hline Baseline: $s_{n k t}^{C N} \times w_{j}$ & & $\begin{array}{l}1.830^{* *} \\
(0.054)\end{array}$ & & & & \\
\hline Alt. IV: US PNTR & & & & $\begin{array}{l}0.399^{* *} \\
(0.022)\end{array}$ & & \\
\hline Alt. IV: MFA Quota fill rate & & & & & & $\begin{array}{l}0.438^{* *} \\
(0.030)\end{array}$ \\
\hline Observations & $1,628,298$ & $1,628,298$ & $1,628,298$ & $1,628,298$ & 399,507 & 399,507 \\
\hline N. Clusters & 44,669 & 44,669 & 44,669 & 44,669 & 9,866 & 9,866 \\
\hline Kleibergen-Paap (F-stat) & & $1,163.9$ & & 337.6 & & 213.4 \\
\hline
\end{tabular}

Note: Standard errors in parentheses clustered at product-destination level. Statistical significance: ${ }^{a}=$ $p<0.1,{ }^{*}=p<0.05,{ }^{* *}=p<0.01$. All specifications include exporter-importer-HS6 and exporterimporter-year FEs. Coefficients for log import demand suppressed in first stage results. Results in columns (5) and (6) are based on the subsample of textiles and clothing industries (HS Chapters 50-63).

We also report results for two alternative identification strategies in which we exploit trade policy changes after China's WTO entry in December 2001. One such policy change was China's transition to permanent normal trade relations (PNTR) with the US, which entailed a lower threat of sudden tariff increases and an expansion of Chinese exports (Pierce and Schott, 2016; Handley and Limão, 2017; Feng et al., 2017). ${ }^{15}$ Mau (2017) shows that the

\footnotetext{
${ }^{15}$ Uncertainty arose from the fact that MFN rates were granted only for one year and were subject to review and approval by the US Congress before being renewed. While the US never actually applied these higher rates on Chinese products, a potential negative decision would have entailed Chinese exporters facing
} 
transition to US PNTR also triggered an acceleration of China's exports to the EU15 and other large high-income destinations. ${ }^{16}$ Following these studies, we measure the productspecific pre-WTO tariff threat faced by Chinese exporters as the difference between US Column-2 and MFN tariff rates $\left(\operatorname{Col} 2_{k}-M F N_{k}\right)$ and interact it with a post-WTO-entry dummy $\left(W T O_{t}^{C N}\right)$. We apply the same destination-specific weight $w_{j}$ as before. Columns (3) and (4) of Table 2 report both reduced-form and second-stage estimation results for this instrument and lend further support to a negative and statistically significant impact of China's expansion on ESE exports. ${ }^{17}$

As a second policy change, we exploit the removal of European quotas in the textiles and clothing industries (HS Chapters 50-63). Quotas were originally imposed on Chinese exports under the Multifibre-Arrangement (MFA) in the 1970s. During our sample period, a first round of quota removals became effective for China upon its WTO entry and a second round followed in 2005. ${ }^{18}$ To evaluate the impact of these removals, we compute for each liberalization round the product-specific quota fill rate (or utilization rate) reported during the three years preceding a specific quota removal. We assume that fill rates indicate how binding a quota actually was, so that higher rates should entail a relatively stronger expansion after the removal. We interact fill rates $\left(f i l_{k}\right)$ with a dummy variable that indicates the quota-free period $\left(\right.$ remove $\left._{k t}\right)$ and with the destination-specific weights $\left(w_{j}\right)$ we have used also for the other instruments. Results are reported in columns (5) and (6) of Table 2 and corroborate previous findings.

Firm-level estimation. Table 3 reports our findings for Bulgarian firm-level exports to EU15 destinations. Columns (1) and (2) show results for our baseline specification without any firm-level controls, besides fixed effects. Both OLS and 2SLS estimates suggest a negative relationship between Chinese market penetration and Bulgarian export revenues. A standard deviation increase of China's EU15 import market share resulted in about 2.44 percent lower

a 28 percentage point increase in applied tariffs on average. At some instances during the 1990s the voting margins in favor of maintaining MFN rates for another year were very small. Upon China's WTO entry, in December 2001, this annual review process was abolished.

${ }^{16}$ Although this event was politically exclusive to US-China trade relations (the EU installed PNTR towards China already in the 1980s), such a "spillover-effect" is in line with theoretical models where firms face significant fixed costs of exporting that are not specific to a particular destination.

${ }^{17}$ We note that the point coefficient in column (4) is quantitatively somewhat larger than in column (2). We attribute this to the simplistic modelling of the time variation for this instrument, which compares only pre- and post-WTO entry periods. Since also standard errors more than double with respect to our baseline IV, this seems to result in a loss of precision in the PNTR-instrument.

${ }^{18}$ Utar $(2014,2018)$ presents a detailed description of the nature and sequence of these events. See Brambilla et al. (2010) for an analysis of US import quotas on Chinese textile and clothing products. The originial data set, specifying quota products, allowed quantities and quota utilization rates was retrieved from the Système Intégré de Gestion de Licenses (SIGL). 
export revenues for an average Bulgarian firm during the six years observed in this sample.

Table 3: China's impact on Bulgarian exports, product and firm-level estimates 2001-2006

\begin{tabular}{|c|c|c|c|c|c|c|}
\hline \multirow[b]{3}{*}{ Dep. var.: log export revenue } & (1) & (2) & \multirow{3}{*}{$\begin{array}{c}(3) \\
\begin{array}{c}\text { Firm } \\
\text { seniority }\end{array} \\
2 \text { SLS }\end{array}$} & \multirow{3}{*}{$\begin{array}{c}(4) \\
\begin{array}{c}\text { Firm } \\
\text { size }\end{array} \\
\text { 2SLS }\end{array}$} & 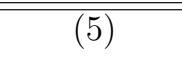 & (6) \\
\hline & \multicolumn{2}{|c|}{$\begin{array}{c}\text { Baseline } \\
\text { specification }\end{array}$} & & & \multicolumn{2}{|c|}{$\begin{array}{c}\text { Alternative IV: } \\
\text { MFA Quotas }\end{array}$} \\
\hline & OLS & 2SLS & & & Red. form & 2SLS \\
\hline \multicolumn{7}{|c|}{ Main results: OLS and second stage } \\
\hline China $\left(s_{j k t}^{C N}\right)$ & $\begin{array}{l}-0.651 \\
(0.786)\end{array}$ & $\begin{array}{l}-1.172^{a} \\
(0.598)\end{array}$ & $\begin{array}{l}-1.185^{*} \\
(0.598)\end{array}$ & $\begin{array}{l}-1.219^{*} \\
(0.596)\end{array}$ & & $\begin{array}{l}-1.455^{a} \\
(0.859)\end{array}$ \\
\hline Years exporting & & & $\begin{array}{l}0.226^{* *} \\
(0.052)\end{array}$ & $\begin{array}{l}0.332^{* *} \\
(0.052)\end{array}$ & $\begin{array}{l}0.385^{* *} \\
(0.102)\end{array}$ & $\begin{array}{l}0.390^{* *} \\
(0.102)\end{array}$ \\
\hline N. of Destinations & & & & $\begin{array}{l}0.068^{* *} \\
(0.023)\end{array}$ & $\begin{array}{l}-0.083^{*} \\
(0.035)\end{array}$ & $\begin{array}{l}-0.083^{*} \\
(0.035)\end{array}$ \\
\hline N. of Products & & & & $\begin{array}{c}-0.259^{* *} \\
(0.018)\end{array}$ & $\begin{array}{l}-0.027 \\
(0.025)\end{array}$ & $\begin{array}{l}-0.026 \\
(0.025)\end{array}$ \\
\hline MFA Quota fill rate & & & & & $\begin{array}{l}-0.465^{a} \\
(0.268)\end{array}$ & \\
\hline Import demand & $\begin{array}{l}0.363^{* *} \\
(0.094)\end{array}$ & $\begin{array}{l}0.229^{* *} \\
(0.025)\end{array}$ & $\begin{array}{l}0.229^{* *} \\
(0.025)\end{array}$ & $\begin{array}{l}0.228^{* *} \\
(0.025)\end{array}$ & $\begin{array}{l}0.208^{* *} \\
(0.032)\end{array}$ & $\begin{array}{l}0.253^{* *} \\
(0.041)\end{array}$ \\
\hline First stage results for $s_{j k t}^{C N}$ & & Baseline & seniority & size & & MFA \\
\hline Baseline: $s_{n k t}^{C N} \times w_{j}$ & & $\begin{array}{l}1.361^{* *} \\
(0.108)\end{array}$ & $\begin{array}{l}1.361^{* *} \\
(0.108)\end{array}$ & $\begin{array}{l}1.361^{* *} \\
(0.108)\end{array}$ & & \\
\hline Alt. IV: MFA Quota fill rate & & & & & & $\begin{array}{l}0.320^{* *} \\
(0.040)\end{array}$ \\
\hline Observations & 268,822 & 268,822 & 268,822 & 268,822 & 113,359 & 113,359 \\
\hline N. Clusters & 15,738 & 15,738 & 15,738 & 15,738 & 4,463 & 4,463 \\
\hline Kleibergen-Paap (F-stat) & & 158.7 & 158.6 & 158.5 & & 63.4 \\
\hline
\end{tabular}

Note: Standard errors reported in parentheses are clustered at the product-destination level. Statistical significance: ${ }^{a}=p<0.1,{ }^{*}=p<0.05,{ }^{* *}=p<0.01$. All specifications include destination-product, destination-year, and firm fixed effects. Coefficients for log import demand and other control variables are suppressed in first stage results. Regression (1) employs weighted OLS, export quantities are used as probability weights. Results in columns (5) and (6) are based on subsample of textiles and clothing industries (HS Chapters 50-63).

Columns (3) and (4) show 2SLS results after including a set of time-varying firm-level controls. We first introduce firm's exporting experience, which we measure by the number of years a firm exports a given HS 6-digits product. ${ }^{19}$ Column (4) includes two additional controls to capture firm size via its diversification (i.e., by counting the maximum number of HS6 products it exports to a specific destination and by counting the maximum number of destinations it serves with a specific HS6 product). Including these variables results in

\footnotetext{
${ }^{19}$ This measure is included in analogy to Utar and Torres Ruiz (2013). Like in our results, they find a positive and significant coefficient which suggests that more experienced firms tend to export more.
} 
a somewhat larger estimated displacement effects of China's expansion, while the standard errors of the coefficients are unaffected at all stages. Estimates reported in column (4) imply that a standard deviation increase in China's market share in the EU15 leads to a 3.33 percent lower revenue for Bulgarian firms. In columns (5) and (6), we also employ our alternative instrument, which exploits the removal of EU import quotas on Chinese textile and clothing products in 2002 and $2005 .{ }^{20}$ As before, this sample focuses only on the relevant HS2 industries, 50-63. This alternative instrument confirms a negative impact of on export revenues on Bulgarian firms and its magnitude is similar to those obtained in our baseline IV specifications reported in columns (2)-(4).

Overall, compared to our product-level results, effects on Bulgarian exporters appear to be quantitatively smaller and less precisely estimated. Nevertheless, one finding that consistently emerges is that OLS coefficients tend to underestimate the true displacement effect of Chinese competition. This suggests that simultaneity bias challenges appropriate identification. Consequently, OLS estimates should be interpreted as a lower bound of the actual displacement effect of China on ESE exports.

\subsection{Differential effects in time-sensitive industries}

We now turn to the central question of this paper and analyze whether ESE exports in time-sensitive industries are less affected by Chinese competition. Such evidence would lend support to the existence of a source of comparative advantage that emerges from the relative ability of a country to ensure timely delivery of its goods to a destination. Our classification of time-sensitive industries follows the methodology of Hummels and Schaur (2013), which we described in Section 2 and Appendix Section B. We adopt binary indicators in our main specifications, which are based on the median HS2-level observation for time-sensitivity.

\subsubsection{Baseline results}

In columns (1) and (2) of Table 4 we employ our simple measure of time-sensitivity and interact this with China's import penetration rate using OLS and 2SLS estimation, respectively. In both specifications, we detect a significantly smaller displacement effect on ESE exports for time-sensitive industries. Columns (3) and (4) confirm this result for the adjusted measure. Across specifications, time-sensitive industries reveal an about 55-65 percent smaller

\footnotetext{
${ }^{20}$ Since our firm-level sample spans a short period, the additional IV employed when replying on productlevel data cannot be used here. This also complicates the use of the quota removals which took place a year after the beginning and a year before the end of our sample period.
} 
displacement relative to their comparison group. ${ }^{21}$

Table 4: China's impact on ESE exports and time-sensitivity, product-level 1997-2007

\begin{tabular}{|c|c|c|c|c|c|c|}
\hline \multirow{4}{*}{$\begin{array}{l}\text { Measure of time-sensitivity: } \\
\text { Specification: } \\
\text { Dep. var.: log export revenue }\end{array}$} & \multirow{2}{*}{\multicolumn{2}{|c|}{$\begin{array}{l}(1) \\
\text { binary (simple) }\end{array}$}} & \multirow{2}{*}{\multicolumn{2}{|c|}{$\begin{array}{lr}(3) & (4) \\
\text { binary } & \text { (strict) }\end{array}$}} & \multirow{2}{*}{\multicolumn{2}{|c|}{$\begin{array}{lr}(5) & (6) \\
\text { binary } & \text { (strict) }\end{array}$}} \\
\hline & & & & & & \\
\hline & \multicolumn{2}{|c|}{ Baseline } & \multicolumn{2}{|c|}{ Baseline } & \multicolumn{2}{|c|}{ add controls } \\
\hline & OLS & 2SLS & OLS & 2SLS & OLS & 2SLS \\
\hline China's market share & $\begin{array}{c}-1.520^{* *} \\
(0.043)\end{array}$ & $\begin{array}{c}-3.081^{* *} \\
(0.163)\end{array}$ & $\begin{array}{c}-1.769^{* *} \\
(0.046)\end{array}$ & $\begin{array}{c}-3.800^{* *} \\
(0.180)\end{array}$ & $\begin{array}{c}-2.343^{* *} \\
(0.106)\end{array}$ & $\begin{array}{c}-5.104^{* *} \\
(0.370)\end{array}$ \\
\hline$\times$ time-sensitive & $\begin{array}{l}0.858^{* *} \\
(0.069)\end{array}$ & $\begin{array}{l}2.547^{* *} \\
(0.212)\end{array}$ & $\begin{array}{l}1.154^{* *} \\
(0.066)\end{array}$ & $\begin{array}{l}3.340^{* *} \\
(0.201)\end{array}$ & $\begin{array}{l}0.925^{* *} \\
(0.072)\end{array}$ & $\begin{array}{l}2.986^{* *} \\
(0.235)\end{array}$ \\
\hline$\times$ intermediate inputs & & & & & $\begin{array}{l}0.719^{* *} \\
(0.095)\end{array}$ & $\begin{array}{l}1.648^{* *} \\
(0.283)\end{array}$ \\
\hline$\times$ contract intensity & & & & & $\begin{array}{l}0.484^{* *} \\
(0.098)\end{array}$ & $\begin{array}{l}1.324^{* *} \\
(0.311)\end{array}$ \\
\hline$\times$ skill intensity & & & & & $\begin{array}{l}0.520^{* *} \\
(0.090)\end{array}$ & $\begin{array}{l}0.994^{* *} \\
(0.289)\end{array}$ \\
\hline Observations & $1,628,298$ & $1,628,298$ & $1,628,298$ & $1,628,298$ & $1,628,298$ & $1,628,298$ \\
\hline N. clusters & 44,669 & 44,669 & 44,669 & 44,669 & 44,669 & 44,669 \\
\hline Kleibergen-Paap (F-stat) & & 609.0 & & 582.0 & & 72.3 \\
\hline
\end{tabular}

Note: Standard errors reported in parentheses are clustered at the product-destination level. Statistical significance: ${ }^{a}=p<0.1,{ }^{*}=p<0.05,{ }^{* *}=p<0.01$. All specifications include log import demand as a control variable (coefficients suppressed) as well as exporter-importer-HS6 and exporter-importer-year FEs.

To test whether these findings mask spurious correlation originating from confounding industry- and product-level characteristics, we include a set of additional interaction terms into our model. A first and obvious suspect are intermediate inputs. This makes intuitive sense if we think of a (European) regional production network where reliable and timely delivery is extremely important and China is less likely to be competitive. We therefore include an additional (binary) interaction term for HS6 products that are classified as intermediate inputs in the Broad Economic Categories (BEC rev.4) nomenclature. ${ }^{22}$ We also consider the possibility that time-sensitivity is correlated with products that are contracting intensive. This would concern activities that are difficult to coordinate because of complex

\footnotetext{
${ }^{21}$ In Table A2 we show that results are similar for continuous measures of time-sensitivity, which we normalized to have mean zero and a standard deviation equal to one. We also ran regressions for separate samples, which we define according to our binary measure of time sensitivity. The coefficient for China's market share is negative and significant in both cases, but smaller in the time-sensitive sample. Based on the average increase in China's market shares in each subsample, OLS results suggest a reduction by 9.1 percent for time-insensitive goods and 5.5 in the time-sensitive subsample, which implies an about 40 percent smaller displacement effect throughout our sample period.

${ }^{22}$ We note that intermediate inputs cannot perfectly capture trade within a supply chain, as parts and components are trade during early stages of the production process. This ignores the possibility that ESE exporters could be involved in the later stages where final goods require timely delivery.
} 
specifications for the production process, where such problems might be easier to overcome if contracting parties are more closely located geographically. We use the contract-intensity measure from Nunn (2007) which measures the share of differentiated production at the industry level. A larger share results in a higher contracting intensity and we employ this measure as a binary indicator that takes a value equal to one for all above-median observations. ${ }^{23}$ Finally, we include a measure of skill intensity, which has revealed as a key dimension for differential exposure in several other studies evaluating the impact of Chinese competition (e.g. Autor et al., 2013; Utar and Torres Ruiz, 2013; Utar, 2014, 2018; Bugamelli et al., 2015). Time-sensitivity and skill intensity could be correlated if timely delivery requires higher management and ICT operation skills. To measure skill intensity, we use data from Amiti and Freund (2010) and include it as an above-median based, binary indicator variable in interaction with China's market share. ${ }^{24}$

Overall, columns (5) and (6) of Table 4 suggest that all our additional attributes reveal comparatively lower displacement of ESE exports. However, we find that the coefficient for time-sensitivity remains positive and highly significant, despite a slight downward correction with respect to columns (3) and (4). Interestingly, adding each of these industry-level characteristics separately into our estimation equation suggests that most of this downward correction can be attributed to the inclusion of intermediate-inputs as control variable (Other controls barely affect the baseline results; see Table A3). This might suggest that time-sensitivity captures indeed a source of comparative advantage that can be attributed to geographic proximity and trade within regional production networks. Skill- and contractingintensity seem to denote separate channels for the determination of trade patterns. Quantitatively, our results in columns (5) and (6) imply an about 40 percent smaller displacement effect of Chinese competition in time-sensitive industries.

\subsubsection{Robustness checks}

Placebo regressions and intra-European distances. Despite robust results for our core findings, we test two additional hypotheses that would be in line with geographic proximity as a source of comparative advantage and clearly reject it if they cannot be supported.

The first test is to estimate the response of other Asian low-wage countries' exports to the EU15. While these countries also compete with China (Eichengreen et al., 2007;

\footnotetext{
${ }^{23}$ The original data from Nunn (2007) reports contract intensity at the 5-digit NAICS level. We use correspondence tables from Pierce and Schott (2009) to map this measure to HS6 products.

${ }^{24}$ Their measure of skill-intensity reflects the share non-production workers in total employment for Indonesian manufacturing industries in 1992. Amiti and Freund (2010) argue that relative factor use in Indonesia's manufacturing sector is a good proxy of relative factor use in China and find that China's export growth during the early 2000s was driven by less skill-intensive products.
} 
Greenaway et al., 2008), they should not be endowed with a geographic proximity advantage in EU15 markets. In columns (1)-(4) of Table 5 we find that, indeed, Asian exporters reveal only weak signs of a differential exposure to Chinese competition in time-sensitive industries. ${ }^{25}$ Although OLS estimates do suggest a smaller displacement effect, this difference is quantitatively much smaller than the one found for ESE exporters. Moreover, it does not find support in our IV specifications. Since most of the other industry characteristics in columns (3) and (4) continue to reveal significantly differential effects, this suggests that that a comparative advantage in time-sensitive industries might be exclusive to the geographically proximate ESE exporters.

Table 5: Time-sensitivity estimates, placebo regressions and ESE distance to EU15

\begin{tabular}{|c|c|c|c|c|c|c|c|c|}
\hline \multirow{4}{*}{$\begin{array}{l}\text { Dependent variable: } \\
\text { Specification: } \\
\text { Dep. var.: log export revenue }\end{array}$} & (1) & $(2)$ & $(3)$ & $(4)$ & $\overline{(5)}$ & $(6)$ & (7) & $(8)$ \\
\hline & \multicolumn{4}{|c|}{ Low-wage Asia's exports (placebo) } & \multicolumn{4}{|c|}{ ESE exports (distances to destination) } \\
\hline & \multicolumn{2}{|c|}{ Baseline } & \multicolumn{2}{|c|}{ add controls } & \multirow{2}{*}{$\frac{\leq 1,500}{\text { OLS }}$} & \multirow{2}{*}{$\begin{array}{c}>1,500 \\
\text { OLS }\end{array}$} & \multicolumn{2}{|c|}{ bilateral distance } \\
\hline & OLS & 2SLS & OLS & 2SLS & & & OLS & 2SLS \\
\hline China's market share & $\begin{array}{c}-0.834^{* *} \\
(0.045)\end{array}$ & $\begin{array}{c}-0.770^{* *} \\
(0.189)\end{array}$ & $\begin{array}{c}-1.064^{* *} \\
(0.096)\end{array}$ & $\begin{array}{c}-1.083^{* *} \\
(0.336)\end{array}$ & $\begin{array}{c}-2.141^{* *} \\
(0.059)\end{array}$ & $\begin{array}{c}-1.100^{* *} \\
(0.061)\end{array}$ & $\begin{array}{c}-2.139^{* *} \\
(0.059)\end{array}$ & $\begin{array}{c}-5.091^{* *} \\
(0.238)\end{array}$ \\
\hline$\times$ time-sensitive & $\begin{array}{l}0.350^{* *} \\
(0.066)\end{array}$ & $\begin{array}{c}0.146 \\
(0.185)\end{array}$ & $\begin{array}{l}0.194^{* *} \\
(0.075)\end{array}$ & $\begin{array}{l}-0.102 \\
(0.224)\end{array}$ & $\begin{array}{l}1.487^{* *} \\
(0.082)\end{array}$ & $\begin{array}{l}0.577^{* *} \\
(0.095)\end{array}$ & $\begin{array}{l}1.487^{* *} \\
(0.082)\end{array}$ & $\begin{array}{l}4.347^{* *} \\
(0.255)\end{array}$ \\
\hline$\times$ intermediate inputs & & & $\begin{array}{l}0.292^{* *} \\
(0.085)\end{array}$ & $\begin{array}{l}0.656^{*} \\
(0.255)\end{array}$ & & & & \\
\hline$\times$ contract intensity & & & $\begin{array}{l}0.186^{*} \\
(0.088)\end{array}$ & $\begin{array}{c}0.322 \\
(0.258)\end{array}$ & & & & \\
\hline$\times$ skill intensity & & & $\begin{array}{l}0.561^{* *} \\
(0.101)\end{array}$ & $\begin{array}{l}0.898^{*} \\
(0.360)\end{array}$ & & & & \\
\hline$\times$ distant $_{i j}$ & & & & & & & $\begin{array}{l}1.030^{* *} \\
(0.079)\end{array}$ & $\begin{array}{l}3.679^{* *} \\
(0.321)\end{array}$ \\
\hline$\times$ time-sens. $\times$ distant $_{i j}$ & & & & & & & $\begin{array}{c}-0.911^{* *} \\
(0.118)\end{array}$ & $\begin{array}{c}-2.769^{* *} \\
(0.351)\end{array}$ \\
\hline Observations & 767,418 & 767,418 & 767,418 & 767,418 & $1,100,535$ & 527,763 & $1,628,298$ & $1,628,298$ \\
\hline N. clusters & 38,703 & 38,703 & 38,703 & 38,703 & 35,630 & 34,525 & 44,669 & 44,669 \\
\hline Kleibergen-Paap (F-stat) & & 431.5 & & 86.5 & & & & 296.2 \\
\hline
\end{tabular}

Note: Standard errors reported in parentheses are clustered at the product-destination level. Statistical significance: ${ }^{a}=p<0.1,{ }^{*}=p<0.05,{ }^{* *}=p<0.01$. All specifications include log import demand as a control variable (coefficients suppressed) as well as exporter-importer-HS6 and exporter-importer-year FEs. The variable distant $_{i j}$ takes a value equal to one for observed bilateral (population-weighted) distances of more than 1,500 kilometers in the CEPII Gravity Dataset.

Our second hypothesis suggests that the proximity advantage should play a more prominent role in short-distance trade relationships between ESE and EU15. To test this, we use bilateral population-weighted distances from the CEPII gravity database and define distant trade relations at a 1,500 kilometer threshold (which roughly reflects the distance between

\footnotetext{
${ }^{25}$ This placebo sample Asian exporters includes: Bangladesh, Cambodia, India, Indonesia, Pakistan, Philippines, Sri Lanka, Thailand, and Vietnam.
} 
the median country pair in our sample). ${ }^{26}$

Columns (5) and (6) of Table 5 report OLS results for sub-samples of geographically proximate and distant country pairs, respectively. Displacement effects appear to be generally smaller for distant trade relations and time-sensitive industries reveal about 50 percent lower displacement in this sample. In the sub-sample of proximate trade partners, time-sensitive industries suggest even 70 lower displacement. In columns (7) and (8) we infer this dimension further by estimating a three-way interaction coefficient for China's market share in the full sample. While time-sensitive industries as well as distant trade relationships appear to be systematically less affected by Chinese competition, we confirm by our three-way interaction at the bottom of the table that the advantage in time-sensitive industries is systematically smaller for ESE exports to relatively distant EU15 destinations. ${ }^{27}$ This suggests that specializing in time-sensitive sectors might shield especially short distance shipments by ESE exporters from Chinese competition.

Firm-level evidence for Bulgaria. In Table A4 we report results on differential responses in time-sensitive industries relying on Bulgarian firm-level data. Despite lower general displacement and Bulgaria's comparatively disadvantageous location in the Southeast of Europe, the main mechanisms should reveal also on this data. Columns (1) and (2) show results for general displacement effects in two sub-samples, reflecting time-insensitive and time-sensitive industries. We define as time-insensitive those industries having a time sensitivity below the median and as time-sensitive those reporting above-the-median time sensitivity. We identify a statistically significant negative coefficient for the effect of Chinese competition only when focusing on firms exporting time-insensitive products. Employing our simple binary measure of time sensitivity in interaction with Chinese expansion, however, does not confirm this result. Columns (3) and (4) suggest that, even if we consider the three highest -quartiles of time-sensitive industries, the interaction coefficient is positive but statistically insignificant. Similar results are found for our strict measure in columns (5) and (6). While OLS results suggest about 50 percent smaller displacement in time-sensitive industries, a statistically significant interaction coefficient is revealed only in our IV specification. Firms in industries characterized by a time sensitivity higher than the first quartile are significantly less affected by Chinese competition in the EU15. These findings suggest that there is a tendency for smaller displacements in time sensitive industries also when

\footnotetext{
${ }^{26}$ According to this threshold, each ESE exporter $i$ has both distant and non-distant EU15 partners $j$. Bulgaria, Romania and Turkey mainly trade on distance (i.e. about 66, 53, and 91 percent of their observed shipments). On the importer side, Ireland, Portugal, and Spain are always classified as distant destinations, while the UK follows with about 65 percent of its observations reflecting distant trade.

${ }^{27}$ Additional estimates using a continuous measure of distance (i.e. log kilometer distance between $i$ and j) confirm results reported here.
} 
employing firm-level data from one of the most remote ESE exporting countries. Yet, this result is much less clear-cut compared to the pooled sample on product-level exports.

Altogether, the robustness checks reported in this section support our conclusion that differential responses to Chinese competition in time-sensitive industries capture an additional source of local comparative advantage for ESE exporters in EU15 destination markets. China and other distant competitors exert lower competitive pressure in such industries, due to their lack of relative supply capacities. As this advantage decays with distance among ESE exporters, it might be most easily exploited by ESE countries that are more centrally located in the European common market.

\section{$5 \quad$ Further results}

In addition to our main findings, we here exploit the rich information in our data to investigate some further dimensions in exporters' adjustments to Chinese competition. We first focus on distinguishing effects on export quantity and unit values to assess which of these two determinants of export revenue is driving the effect of Chinese competition on export performance. Furthermore, we investigate heterogeneous effects across ESE countries and firms.

\subsection{Quantities and unit-values}

Table 6 displays results jointly for product-level ESE exports (Panel A) and firm-level Bulgarian exports (Panel B). We can compare them to those for export revenues, shown in Tables 2 and 3 of the previous section. Columns (1) and (2) report baseline OLS and IV estimates for the effect of Chinese competition on the quantity of exports, while columns (3) and (4) present findings for quantity adjustments in time-sensitive industries (using our strict measure). Corresponding results for export unit-values are shown in columns (5)-(8).

Starting with Panel A, coefficients for China's impact on ESE export quantities are somewhat smaller than those identified previously for export revenues. Based on China's observed expansion during the sample period, export volumes decrease by 5.6 percent according to the OLS specification in column (1). This corresponds to about 84 percent of the previously estimated 6.8 percent reduction in export revenues. The remaining 16 percent can be attributed to lower average unit values, as reported in column (5). We find similar relative contributions in our IV specifications. Firm-level regressions in Panel B suggest different patterns. In contrast to our previous findings for firm-level export revenues, export quantities reveal a sharp reduction while export unit values increase in response to Chinese competition. The 
Table 6: Volume and unit values of exports, product-level estimates on ESE sample and firm-level estimates on Bulgarian exporters

\begin{tabular}{|c|c|c|c|c|c|c|c|c|}
\hline & 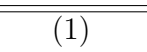 & $\overline{(2)}$ & $\overline{(3)}$ & $(4)$ & $\overline{(5)}$ & $\overline{(6)}$ & $\overline{(7)}$ & $(8)$ \\
\hline $\begin{array}{l}\text { Panel A: Product-level es } \\
\text { Dependent variable: }\end{array}$ & \multicolumn{8}{|c|}{ Panel A: Product-level estimates } \\
\hline & OLS & 2SLS & OLS & 2SLS & OLS & 2SLS & OLS & 2SLS \\
\hline China $\left(s_{j k t}^{C N}\right)$ & $\begin{array}{c}-1.024^{* *} \\
(0.040)\end{array}$ & $\begin{array}{c}-1.879^{* *} \\
(0.178)\end{array}$ & $\begin{array}{c}-1.581^{* *} \\
(0.049)\end{array}$ & $\begin{array}{c}-3.374^{* *} \\
(0.194)\end{array}$ & $\begin{array}{c}-0.198^{* *} \\
(0.018)\end{array}$ & $\begin{array}{c}-0.463^{* *} \\
(0.075)\end{array}$ & $\begin{array}{c}-0.188^{* *} \\
(0.023)\end{array}$ & $\begin{array}{c}-0.426^{* *} \\
(0.083)\end{array}$ \\
\hline$\times$ time-sensitive & & & $\begin{array}{l}1.176^{* *} \\
(0.075)\end{array}$ & $\begin{array}{l}3.425^{* *} \\
(0.225)\end{array}$ & & & $\begin{array}{l}-0.021 \\
(0.034)\end{array}$ & $\begin{array}{l}-0.086 \\
(0.094)\end{array}$ \\
\hline Observations & $1,628,298$ & $1,628,298$ & $1,628,298$ & $1,628,298$ & $1,628,298$ & $1,628,298$ & $1,628,298$ & $1,628,298$ \\
\hline N. Cluster & 44,669 & 44,669 & 44,669 & 44,669 & 44,669 & 44,669 & 44,669 & 44,669 \\
\hline Kleibergen-Paap (F-stat) & & $1,163.9$ & & 582.0 & & $1,163.9$ & & 582.0 \\
\hline \multicolumn{9}{|c|}{ Panel B: Firm-level estimates } \\
\hline & OLS & 2SLS & OLS & $2 \mathrm{SLS}$ & OLS & 2SLS & OLS & 2SLS \\
\hline China $\left(s_{j k t}^{C N}\right)$ & $\begin{array}{c}-0.585^{*} \\
(0.242)\end{array}$ & $\begin{array}{c}-2.167^{* *} \\
(0.599)\end{array}$ & $\begin{array}{c}-0.732^{* *} \\
(0.137)\end{array}$ & $\begin{array}{c}-2.723^{* *} \\
(0.624)\end{array}$ & $\begin{array}{c}0.059 \\
(0.052)\end{array}$ & $\begin{array}{l}0.948^{* *} \\
(0.290)\end{array}$ & $\begin{array}{l}0.194^{* *} \\
(0.057)\end{array}$ & $\begin{array}{l}1.345^{* *} \\
(0.284)\end{array}$ \\
\hline$\times$ time-sensitive & & & $\begin{array}{l}0.804^{* *} \\
(0.200)\end{array}$ & $\begin{array}{l}2.579^{* *} \\
(0.626)\end{array}$ & & & $\begin{array}{c}-0.341^{* *} \\
(0.103)\end{array}$ & $\begin{array}{c}-1.843^{* *} \\
(0.326)\end{array}$ \\
\hline Observations & 268,822 & 268,822 & 268,822 & 268,822 & 268,822 & 268,822 & 268,822 & 268,822 \\
\hline N. Cluster & 15,738 & 15,738 & 15,738 & 15,738 & 15,738 & 15,738 & 15,738 & 15,738 \\
\hline Kleibergen-Paap (F-stat) & & 158.516 & & 68.747 & & 158.516 & & 68.747 \\
\hline
\end{tabular}

Note: Standard errors in parentheses adjusted for clustering at the destination-product level. Statistical significance: ${ }^{a}=p<0.1,{ }^{*}=p<0.05,{ }^{* *}=p<0.01$. Log import demand included in all specifications, but not reported. Panel A: all specifications include exporter-destination-product and exporter-destination-year fixed effects. Panel B: all specifications include destination-product, destination-year, and firm fixed effects. Firm-level controls have been included but are not reported here (Firm seniority, N. of Products, N. of Destinations).

increase is substantial and compensates almost 50 percent of the revenues lost due to lower export volumes. Since quantity effects in column (2) appear fairly similar in Panels A and $\mathrm{B}$, these results indicate that heterogeneous responses across ESE exporters might be driven also by differential responses in unit-values. Although such differential effects could be due to several factors, one explanation for the case of Bulgaria could be that their relatively high FDI inflows facilitated quality upgrading of firms' exports. ${ }^{28}$

Turning to the differential responses in time-sensitive industries, we observe in Panel A that they can be fully attributed to smaller displacement effects of export volumes. This suggests that ESE's local comparative advantage in time-sensitive exports does not originate

\footnotetext{
${ }^{28}$ We consider FDI inflows as a potential source of higher resilience to Chinese competition in the discussion of heterogeneous effects across ESE countries in Appendix Section C.1. Ciani and Imbruno (2017) find that FDI inflows contributed to average improvements of export quality among Bulgarian firms thanks to positive forward spillovers.
} 
from any systematic differences in the price response to Chinese competition, but instead reflects higher resilience to external competition. Similar conclusions can be drawn from the firm-level results reported in columns (3) and (4) of Panel B, where export quantities in timesensitive industries are significantly less affected by Chinese competition. Moreover, while export unit-values of Bulgarian firms increase as Chinese competition intensifies, unit-values in time-sensitive sectors do not adjust accordingly. Export unit-values in time-sensitive industries decrease, suggesting that firms lack incentives to upgrade their products due to Chinese competition as long as they benefit from a comparative advantage in accessing the destination market.

\subsection{Heterogeneous effects across exporters}

In this final subsection, we shift our focus towards heterogeneous effects across exporters. We investigate the existence and potential reasons for differential effects across exporting ESE countries. Relying on information from our firm-level data, we also report findings on differential effects across exporting firms.

Effects across exporting countries. In Appendix C, we present an extensive analysis of potential heterogeneous effects across ESE countries in our sample. We conclude that, overall, our baseline results can be viewed as being fairly representative, although some systematic differences appear across exporting countries (see Figures C1-C3). As shown in Table $\mathrm{C} 1$, the eight Eastern European countries (EEC) reveal systematically larger reductions in exports than the Southeast European (SEE) economies. While part of this difference can be attributed to an influential outlier in the comparison group (Turkey appears to be quite resilient to Chinese competition), several exporting country characteristics at the beginning of our sample period seem to play a role. Countries integrating earlier into the European Union tend to be generally more affected. Moreover, we observe that exporters with higher real GDP per capita, lower average price levels, and higher inflows of FDI (in percent of GDP) are relatively less affected. High FDI inflows and low price levels could, for instance, explain why Czech Republic's exports respond less to Chinese competition than its neighbors, Poland and Slovakia. We also find that displacement effects are smaller in Bulgaria, where FDI inflows were higher and price levels lower than in most other ESE countries (Figure C4).

Effects across firms. In Table C2, we focus on heterogeneous effects across firms, which we investigate by interacting Chinese expansion with different firm-level characteristics. Columns (1) and (2) report OLS and 2SLS results obtained when interacting China's market 
share with a firm-level indicator, which proxies its relative size based on total export revenues in the first year we observe it in our data. Firms residing in the top $25^{\text {th }}$ percentile of the revenue distribution are considered as being large. Estimates show that these firms are significantly less affected by Chinese competition, which suggests that large firm are either sufficiently productive or more capable in diversifying their export strategies to avoid major displacements of their exports.

In columns (3) and (4), the interaction variable is a binary time-invariant indicator for firms that sold any of their goods to more than one destination, upon the first observation. Both OLS and 2SLS estimates now suggest a large and significant displacement effect for the majority of geographically less diversified firms (recall that the median firm in our sample exports the average product to only one destination), while multi-destination exporters are systematically less affected. On the contrary, results in columns (5) and (6) suggest that multi-product exporter (i.e. firms selling several HS6 products to a single destination) are not differently affected by Chinese competition.

\section{Conclusion}

We analyzed the impact of increased Chinese competition in EU15 markets on export revenues of 16 Eastern and Southeast European countries in the early 2000s. Our identification strategy exploits the exogenous intensification of Chinese competition within narrow destination-product markets, which we derive from the evolution of Chinese exports in comparable high-income markets and from trade linkages existing before China's accession to the WTO.

We find that export revenues of ESE countries decline in response to China's expansion and confirm this result also in an auxiliary database of Bulgarian firms. Displacements are sizeable and comparable to those found in related studies investigating the displacement of emerging countries' exports in other developed markets due to Chinese expansion (Utar and Torres Ruiz, 2013).

Interestingly, we find that export reductions are substantially smaller in industries for which timely delivery matters. This result suggests the existence of a local comparative advantage in time-sensitive industries ESE exporters derive from their geographic proximity and shorter delivery times to the EU15. Firms' or countries' ability to ensure timely delivery reveals as an important determinant of competitiveness. Indeed, time sensitivity plays a major role in sheltering ESE countries more closely located to the EU15 from Chinese competition and its effect is not driven by trade flows in intermediate inputs and by the skill intensity of traded goods. 
We also provide new evidence explaining differential effects across exporters, by showing that China's impact varies depending on initial exporter conditions, such as average price levels or FDI inflows at the beginning of the sample period. We confirm that the reductions in export revenues reflect actual exporting activity, as they are mainly explained by reductions in export quantities. Moreover, our firm-level analysis suggests that larger and multi-destination exporters are systematically less affected by Chinese competition.

From a policy perspective, our findings imply that specializing in time-sensitive industries and providing a functional transport infrastructure can shield exporters from external competition. Providing such infrastructure may be viewed as a complementary strategy to investments in training and education, which foster comparative advantage in skill-intensive activities. Another implication of this result is that exporters located too far away from a specific destination market face a substantial barrier to accessing particular market segments and develop supply capacities in specific industries. In this respect, prolonged delivery times to (and distance from) large high-income markets may impose limits to countries' export diversification potential. 


\section{References}

Adams, F. G., Gangnes, B., and Shachmurove, Y. (2006). Why is China so Competitive? Measuring and Explaining China's Competitiveness. World Economy, 29(2):95-122.

Amann, E., Lau, B., and Nixson, F. (2009). Did China Hurt the Textiles and Clothing Exports of Other Asian Economies, 1990-2005? Oxford Development Studies, 37(4):333362.

Amiti, M. and Freund, C. (2010). The Anatomy of China's Export Growth. In China's Growing Role in World Trade, NBER Chapters, pages 35-56. National Bureau of Economic Research, Inc.

Autor, D. H., Dorn, D., and Hanson, G. H. (2013). The China Syndrome: Local Labor Market Effects of Import Competition in the United States. American Economic Review, 103(6):2121-68.

Autor, D. H., Dorn, D., Hanson, G. H., and Song, J. (2014). Trade Adjustment: WorkerLevel Evidence. The Quarterly Journal of Economics, 129(4):1799-1860.

Bartik, T. J. (1991). Who Benefits from State and Local Economic Development Policies? Number wbsle in Books from Upjohn Press. W.E. Upjohn Institute for Employment Research.

Bernard, A. B., Jensen, J. B., and Schott, P. K. (2006). Survival of the Best Fit: Exposure to Low-wage Countries and the (Uneven) Growth of U.S. Manufacturing Plants. Journal of International Economics, 68(1):219-237.

Bloom, N., Draca, M., and Van Reenen, J. (2016). Trade Induced Technical Change? The Impact of Chinese Imports on Innovation, IT and Productivity. The Review of Economic Studies, 83(1):87-117.

Brambilla, I., Khandelwal, A. K., and Schott, P. K. (2010). China's Experience under the Multi-Fiber Arrangement (MFA) and the Agreement on Textiles and Clothing (ATC). In Feenstra, R. C. and Wei, S.-J., editors, China's Growing Role in World Trade, National Bureau of Economic Research Conference Report, pages 345-387. University of Chicago Press.

Bugamelli, M., Fabiani, S., and Sette, E. (2015). The Age of the Dragon: The Effect of Imports from China on FirmLevel Prices. Journal of Money, Credit and Banking, 47(6):1091-1118.

Ciani, A. and Imbruno, M. (2017). Microeconomic mechanisms behind export spillovers from FDI: evidence from Bulgaria. Review of World Economics (Weltwirtschaftliches Archiv), 153(4):703-734.

Dauth, W., Findeisen, S., and Südekum, J. (2014). The Rise Of The East And The Far East: German Labor Markets And Trade Integration. Journal of the European Economic Association, 12(6):1643-1675. 
Deardorff, A. V. (2014). Local comparative advantage: Trade costs and the pattern of trade. International Journal of Economic Theory, 10(1):9-35.

Djankov, S., Freund, C., and Pham Cong, S. (2010). Trading on time. Review of Economics and Statistics, 92(1):166-173.

Eaton, J. and Kortum, S. (2002). Technology, Geography, and Trade. Econometrica, 70(5):1741-1779.

Eichengreen, B., Rhee, Y., and Tong, H. (2007). China and the Exports of Other Asian Countries. Review of World Economics (Weltwirtschaftliches Archiv), 143(2):201-226.

Evans, C. L. and Harrigan, J. (2005). Distance, time, and specialization: Lean retailing in general equilibrium. The American Economic Review, 95(1):292-313.

Feenstra, R. C. and Hanson, G. H. (2004). Intermediaries in Entrepot Trade: Hong Kong Re-Exports of Chinese Goods. Journal of Economics \& Management Strategy, 13(1):3-35.

Feng, L., Li, Z., and Swenson, D. L. (2017). Trade policy uncertainty and exports: Evidence from China's WTO accession. Journal of International Economics, 106(C):20-36.

Fernandes, A., Freund, C., and Pierola, M. (2016). Exporter behavior, country size and stage of development: Evidence from the exporter dynamics database. Journal of Development Economics, 119:121 - 137.

Flückiger, M. and Ludwig, M. (2015). Chinese Export Competition, Declining Exports and Adjustments at the Industry and Regional Level in Europe. Canadian Journal of Economics, 48(3):1120-1151.

Greenaway, D., Mahabir, A., and Milner, C. (2008). Has China Displaced other Asian Countries' Exports? China Economic Review, 19(2):152-169.

Handley, K. and Limão, N. (2017). Policy Uncertainty, Trade, and Welfare: Theory and Evidence for China and the United States. American Economic Review, 107(9):27312783.

Hanson, G. H. and Robertson, R. (2010). China and the Manufacturing Exports of Other Developing Countries. In China's Growing Role in World Trade, NBER Chapters, pages 137-159. National Bureau of Economic Research, Inc.

Holmes, T. J. and Stevens, J. J. (2014). An alternative theory of the plant size distribution, with geography and intra- and international trade. Journal of Political Economy, $122(2): 369-421$.

Hornok, C. (2012). Need for Speed: Is Faster Trade in the EU Trade-creating? MNB Working Papers 2012/4, Magyar Nemzeti Bank (Central Bank of Hungary).

Hummels, D. L. and Schaur, G. (2013). Time as a trade barrier. American Economic Review, 103(7):2935-59. 
Khandelwal, A. (2010). The Long and Short (of) Quality Ladders. Review of Economic Studies, 77(4):1450-1476.

Mattoo, A., Mishra, P., and Subramanian, A. (2017). Beggar-Thy-Neighbor Effects of Exchange Rates: A Study of the Renminbi. American Economic Journal: Economic Policy, 9(4):344-366.

Mau, K. (2017). US policy spillover(?) Chinas accession to the WTO and rising exports to the EU. European Economic Review, 98(C):169-188.

Mau, K. (2019). Foreign competition and quality sorting: Overlaps in US and Chinese exports. The World Economy, 42(8):2300-2325.

Moulton, B. R. (1990). An Illustration of a pitfall in estimating the effects of aggregate variables in micro units. Review of Economics and Statistics, 72(2):354-338.

Nordås, H., Pinali, E., and Geloso Grosso, M. (2006). Logistics and Time as a Trade Barrier. Trade Policy Papers 35, OECD.

Nunn, N. (2007). Relationship-Specificity, Incomplete Contracts, and the Pattern of Trade. The Quarterly Journal of Economics, 122(2):569-600.

Pierce, J. R. and Schott, P. K. (2009). A Concordance Between Ten-Digit U.S. Harmonized System Codes and SIC/NAICS Product Classes and Industries. NBER Working Papers 15548, National Bureau of Economic Research, Inc.

Pierce, J. R. and Schott, P. K. (2016). The Surprisingly Swift Decline of U.S. Manufacturing Employment. American Economic Review, 106(7):1632-62.

Schott, P. K. (2008). The Relative Sophistication of Chinese Exports. Economic Policy, 23:5-49.

Silgoner, M., Steiner, K., Wörz, J., and Schitter, C. (2015). Fishing in the Same Pool: Export Strengths and Competitiveness of China and Central, Eastern and Southeastern Europe at the EU-15 market. China Economic Review, 32(C):68-83.

Utar, H. (2014). When the Floodgates Open: "Northern" Firms' Response to Removal of Trade Quotas on Chinese Goods. American Economic Journal: Applied Economics, $6(4): 226-50$.

Utar, H. (2018). Workers Beneath the Floodgates: Impact of Low-Wage Import Competition and Workers' Adjustment. Review of Economics and Statistics, 100(4):631-647.

Utar, H. and Torres Ruiz, L. B. (2013). International Competition and Industrial Evolution: Evidence from the Impact of Chinese Competition on Mexican Maquiladoras. Journal of Development Economics, 105(C):267-287. 


\section{Appendix}

\section{A Identification and robustness}

\section{A.1 Reverse causality and spurious correlation}

In the context of our study, reverse causality can be illustrated with a simple gravity model. Consider a simplified characterization of market shares following Eaton and Kortum (2002):

$\pi_{j m}=\frac{\left(c_{m} \tau_{j m}\right)^{-\theta}}{\sum_{h}\left(c_{h} \tau_{j h}\right)^{-\theta}}$, where $\pi_{j m}$ denotes exporter $m$ 's fraction in $j$ 's total consumption, $c_{m}$ are unit production costs in country $m$ and $\tau_{j m} \geq 1$ denotes bilateral trade barriers. For $m$ being China, market shares change if the numerator (supply conditions in China) or the denominator (supply conditions in the rest of the world, including China and all ESE exporters $i$ ) change. China's market share depends on its supply capacities relative to all other countries, while any causal effect attributable to China requires that changes stem from its absolute supply capacities. For instance, reverse causality would occur if ESE exporters' internal structural adjustments allow China to expand in markets previously occupied by these exporters. Although this would not reject our hypothesis that Chinese and ESE product varieties are substitutes, the underlying causal force would come from the ESE economies and not from China. Similarly, preference shifts towards Chinese varieties could increase its market share at the expense of ESE exports, while both absolute and relative supply capacities are unchanged. In this case, a negative coefficient for China $_{j k t}$ would originate from spurious correlation, and in both cases, our estimate of $\beta$ would be inflated and suggest greater than actual displacement of ESE exports due to Chinese competition.

We note that it is also possible that our OLS coefficient exerts attenuation bias. During the period we observe, the majority of countries in our sample integrated with EU15 markets. Either through attaining EU membership candidate status or becoming full members. Besides an almost complete removal of tariff barriers, this entailed also inflows of foreign investment from EU15 countries. Noting that, from the viewpoint of our importing economies, most ESE countries and China had a comparative advantage in labor- and low-skill intensive production, trade liberalization and investments could have spurred growth and productivity in sectors where China expanded, as well. Indeed, there could even be complementarity in sourcing from China and ESE if trade patterns are driven by general trends in offshoring labor-intensive production activities. As a result, we would observe that our OLS coefficient understates actual displacement effects, due to a simultaneity bias where ESE and Chinese exports grow at the expense of economically more advanced exporters outside our sample. We back up our OLS results by employing an instrumental variables approach to extract variation in China's expansion that can be attributed exclusively to changes in its own supply 
capacities.

\section{A.2 Bartik IV and caveats to identification}

Despite its wide use in the empirical literature, the product-level dimension of our instrument leaves the actual causal source of China's expansion unobserved. According to Autor et al. (2013), it is still possible that demand shocks for imports from low-wage countries (including China and ESE) are correlated across EU15 and other high-income economies. In this event, both our OLS and instrumental variable coefficient would understate the true effect of Chinese competition. However, since our descriptive statistics suggest that the ESE countries mainly export to EU15 destinations, while another large fraction accounts for trade among ESE countries, we argue that simultaneity bias is less likely to play a major role in our instrumental variable.

Another concern could be that China's expansion into high-income markets not only resulted from its own economic reforms and trade liberalizations, but instead resulted from independent, yet complementary, technological change. The late 1990s and early 2000s witnessed major advancements in information and communication technologies (ICTs), which facilitated international outsourcing and offshore production. In this case, China's expansion would not be exogenous from the viewpoint of a country that contributed to these technological advancements. While this could pose an important threat for identification of import competition in the EU15, we suppose that for our group of exporters Chinese competition is less likely to be a home-made phenomenon. In our robustness checks we implicitly control for this possibility by adding additional fixed effects into our empirical model. As a more general approach to addressing these concerns, we also employ an alternative identification strategy which exploits China's WTO entry as a quasi-natural experiment to generate variation in exposure to Chinese competition at the HS6 product level.

\section{A.3 Hong Kong re-exports weight}

Figure A1 shows how Chinese imports of Hong Kong transportation services decline after 2002. The reduction suggests that lower trade barriers allowed China to rely less on shipments via Hong Kong ports and instead to export directly to the final destination markets. A2 displays to which EU15 destinations Hong Kong re-exports were mostly shipped during the years before China's WTO entry. Countries where Hong Kong re-exports concentrated

are expected to experience relatively stronger expansions of Chinese exports after its WTO entry. 
Figure A1: Chinese imports of transportation services from Hong Kong, share of total

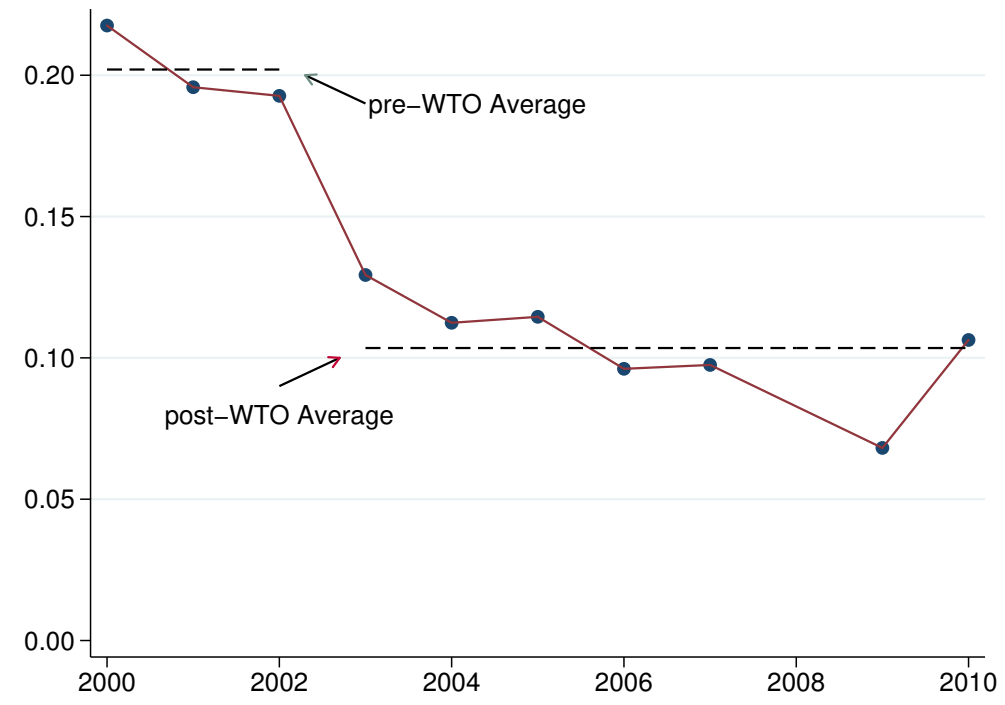

Note: Authors' calculations based on data from World Bank Trade in Services Database (https://data. worldbank.org/data-catalog/trade-in-services). Data starts in 2000, information for 2008 missing.

Figure A2: Distribution of Hong Kong re-exports across EU15 destinations, 1999-2001

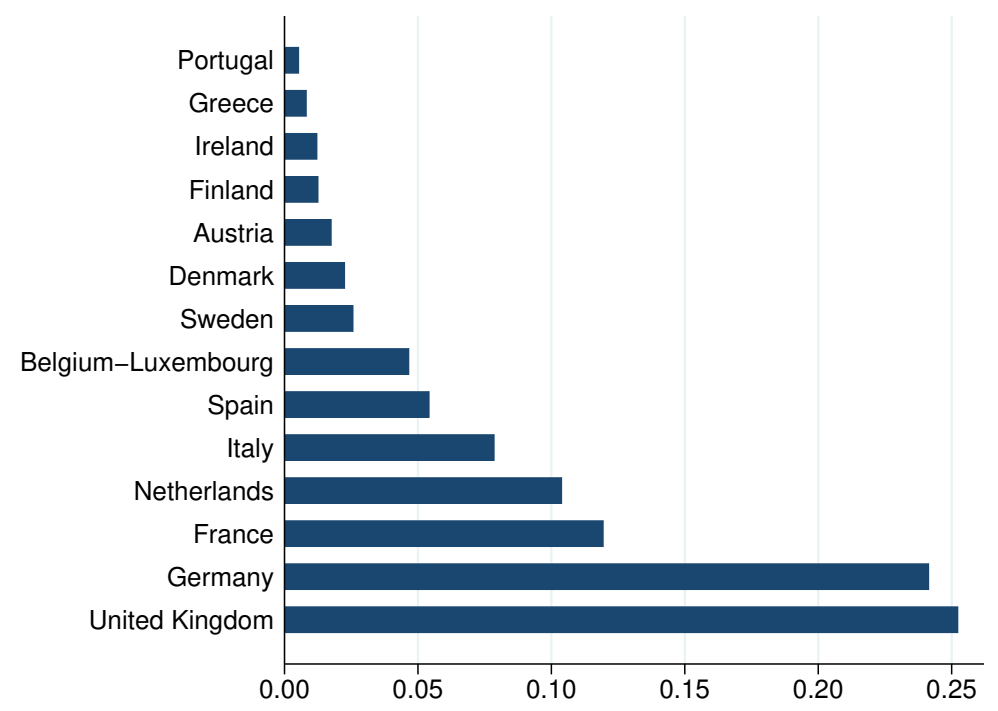

Note: Authors' calculations based on data from UN Comtrade. Shares indicate fractions of total Hong Kong re-exports to EU15 destinations. 


\section{A.4 Robustness of general displacement effects}

We submitted our baseline results from Table 2 to a number of robustness checks, which are summarized in Table A1.

Table A1: Robustness of China's impact on ESE exports, product-level estimates

\begin{tabular}{|c|c|c|c|c|c|c|c|c|c|c|}
\hline & (1) & (2) & (3) & (4) & (5) & (6) & (7) & (8) & (9) & (10) \\
\hline & \multicolumn{4}{|c|}{ Clustering and aggregation } & \multicolumn{6}{|c|}{ Additional fixed effects and controls } \\
\hline & \multicolumn{2}{|c|}{ Cluster HS6 } & \multicolumn{2}{|c|}{$\begin{array}{c}\text { Aggregate } \\
\text { destinations }\end{array}$} & \multicolumn{2}{|c|}{ HS6-year FE } & \multicolumn{2}{|c|}{ Additional control } & \multicolumn{2}{|c|}{$\begin{array}{c}\text { Exporter-HS6-year } \\
\text { FE }\end{array}$} \\
\hline & OLS & IV & OLS & IV & OLS & IV & OLS & IV & OLS & IV \\
\hline China $\left(s_{j k t}^{C N}\right)$ & $\begin{array}{c}-1.222^{* *} \\
(0.058)\end{array}$ & $\begin{array}{l}-2.343^{* *} \\
(0.240)\end{array}$ & $\begin{array}{c}-1.529^{* *} \\
(0.108)\end{array}$ & $\begin{array}{l}-2.044^{* *} \\
(0.267)\end{array}$ & $\begin{array}{c}-0.661^{* *} \\
(0.032)\end{array}$ & $\begin{array}{l}-2.026^{* *} \\
(0.548)\end{array}$ & $\begin{array}{c}-0.661^{* *} \\
(0.032)\end{array}$ & $\begin{array}{l}-2.040^{* *} \\
(0.549)\end{array}$ & $\begin{array}{c}-0.646^{* *} \\
(0.036)\end{array}$ & $\begin{array}{l}-2.293^{* *} \\
(0.590)\end{array}$ \\
\hline Import demand & $\begin{array}{l}0.569^{* *} \\
(0.010)\end{array}$ & $\begin{array}{l}0.576^{* *} \\
(0.010)\end{array}$ & $\begin{array}{l}0.588^{* *} \\
(0.017)\end{array}$ & $\begin{array}{l}0.589^{* *} \\
(0.017)\end{array}$ & $\begin{array}{l}0.429^{* *} \\
(0.006)\end{array}$ & $\begin{array}{l}0.435^{* *} \\
(0.006)\end{array}$ & $\begin{array}{l}0.429^{* *} \\
(0.006)\end{array}$ & $\begin{array}{l}0.435^{* *} \\
(0.006)\end{array}$ & $\begin{array}{l}0.448^{* *} \\
(0.007)\end{array}$ & $\begin{array}{l}0.456^{* *} \\
(0.007)\end{array}$ \\
\hline Applied tariff & & & & & & & $\begin{array}{l}-2.459^{* *} \\
(0.136)\end{array}$ & $\begin{array}{c}-2.454^{* *} \\
(0.136)\end{array}$ & & \\
\hline Observations & $1,628,298$ & $1,628,298$ & 394,071 & 394,071 & $1,626,480$ & $1,626,480$ & $1,626,480$ & $1,626,480$ & $1,516,895$ & $1,516,895$ \\
\hline N. Clusters & 3,903 & 3,903 & 3,921 & 3,921 & 44,344 & 44,344 & 44,344 & 44,344 & 42,795 & 42,795 \\
\hline Kleibergen-Paap (F-stat) & & 444.9 & & 411.0 & & 191.0 & & 191.1 & & 178.2 \\
\hline Clustering dimension & HS6 & HS6 & HS6 & HS6 & HS6-dest. & HS6-dest. & HS6-dest. & HS6-dest. & HS6-dest. & HS6-dest. \\
\hline Exporter-importer-year FE & $\checkmark$ & $\checkmark$ & & & $\checkmark$ & $\checkmark$ & $\checkmark$ & $\checkmark$ & $\checkmark$ & $\checkmark$ \\
\hline Exporter-importer-HS6 FE & $\checkmark$ & $\checkmark$ & & & $\checkmark$ & $\checkmark$ & $\checkmark$ & $\checkmark$ & $\checkmark$ & $\checkmark$ \\
\hline Exporter-year FE & & & $\checkmark$ & $\checkmark$ & & & & & & \\
\hline Exporter-HS6 FE & & & $\checkmark$ & $\checkmark$ & & & & & & \\
\hline HS6-year FE & & & & & $\checkmark$ & $\checkmark$ & $\checkmark$ & $\checkmark$ & & \\
\hline Exporter-HS6-year FE & & & & & & & & & $\checkmark$ & $\checkmark$ \\
\hline
\end{tabular}

Note: Standard errors in parentheses adjusted for clustering in different dimensions. Statistical significance: ${ }^{a} p<0.1,{ }^{*} p<0.05,{ }^{* *} p<0.01$

First, we adjust standard errors for clustering at the HS6-product level. As expected, columns (1) and (2) show that fewer clusters increase the standard error of our main coefficient, but it remains highly statistically significant. In columns (3) and (4), we aggregate variables over all destination markets and treat the EU15 as a single destination. Although standard errors are again somewhat larger, both OLS and IV estimates confirm magnitudes and significance of the previously estimated effects. In the following, we include additional fixed effects and control variables. We first include an additional set of product-year fixed effects to control for omitted variable bias stemming from a correlation of China's expansion with general product-level dynamics. While our OLS coefficient for China in column (5) becomes indeed smaller in absolute terms, the corresponding IV coefficient reported in column (6) is essentially unchanged. The same finding reveals in columns (7) and (8) where we include the applied EU tariff on ESE countries' products as an additional control variable. In the final two columns, we allow for the possibility that our main variable of interest is correlated with exporter-specific product portfolio dynamics and include exporter-HS6year effects. Note that this specification implicitly controls for ESE countries' imports from China, which might affect their exporting behavior either through competition in the domes- 
tic market or through imports of intermediate inputs and other changes in their production functions. Despite removing substantial variation in our data by such a specification, we find again that our OLS estimate is lower compared to the baseline, but that our IV coefficient is only marginally affected (i.e., -2.293 instead of -2.343 ).

\section{A.5 Robustness of time-sensitivity results}

Tables in this subsection present results for alternative specifications that support a differential (smaller) displacement effect of Chinese competition in time-sensitive industries. Table A2 uses a continuous measure of time-sensitivity instead of the binary indicator used in the main text. Table A3 reports results for time-sensitivity after controlling separately for the potentially confounding factors discussed in the main text. Table A4 presents time-sensitivity results for our firm-level sample of Bulgarian exporters.

Table A2: Continuous time-sensitivity measure, broad and strict; product-level estimates 1997-2007

\begin{tabular}{|c|c|c|c|c|}
\hline \multirow{3}{*}{$\begin{array}{l}\text { Measure of time-sensitivity: } \\
\text { Dep. var.: log export revenue }\end{array}$} & \multirow{2}{*}{\multicolumn{2}{|c|}{$\begin{array}{l}(1) \\
\text { Broad }(\mathrm{SD}=1)\end{array}$}} & \multirow{2}{*}{\multicolumn{2}{|c|}{$\begin{array}{l}(3) \\
\text { Strict }(\mathrm{SD}=1)\end{array}$}} \\
\hline & & & & \\
\hline & OLS & 2SLS & OLS & 2SLS \\
\hline China's market share & $\begin{array}{c}-1.006^{* *} \\
(0.041)\end{array}$ & $\begin{array}{c}-1.660^{* *} \\
(0.183)\end{array}$ & $\begin{array}{c}-1.134^{* *} \\
(0.036)\end{array}$ & $\begin{array}{c}-2.064^{* *} \\
(0.158)\end{array}$ \\
\hline$\times$ time-sensitive & $\begin{array}{l}0.841^{* *} \\
(0.083)\end{array}$ & $\begin{array}{l}2.476^{* *} \\
(0.311)\end{array}$ & $\begin{array}{l}0.597^{* *} \\
(0.042)\end{array}$ & $\begin{array}{l}1.687^{* *} \\
(0.128)\end{array}$ \\
\hline Observations & $1,628,298$ & $1,628,298$ & $1,628,298$ & $1,628,298$ \\
\hline N. clusters & 44,669 & 44,669 & 44,669 & 44,669 \\
\hline Kleibergen-Paap (F-stat) & & 595.1 & & 609.0 \\
\hline
\end{tabular}

Note: Standard errors reported in parentheses are clustered at the product-destination level. Statistical significance: ${ }^{a}=p<0.1,{ }^{*}=p<0.05,{ }^{* *}=p<0.01$. All specifications include log import demand as a control variable (coefficients suppressed) as well as exporter-importer-HS6 and exporter-importer-year FEs. 
Table A3: Time-sensitivity estimates, individual inclusion of controls

\begin{tabular}{|c|c|c|c|c|c|c|}
\hline \multirow{3}{*}{$\begin{array}{l}\text { Control variable: } \\
\text { Dep. var.: log exports }\end{array}$} & (1) & $\overline{(2)}$ & $\overline{(3)}$ & $\overline{(4)}$ & $\overline{(5)}$ & 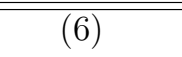 \\
\hline & \multicolumn{2}{|c|}{$\begin{array}{l}\text { intermediate inputs } \\
\text { BEC (rev.4) }\end{array}$} & \multicolumn{2}{|c|}{$\begin{array}{l}\text { contract intensity } \\
\text { Nunn (2007) }\end{array}$} & \multicolumn{2}{|c|}{$\begin{array}{c}\text { skill intensity } \\
\text { Amiti and Freund (2010) }\end{array}$} \\
\hline & OLS & 2SLS & OLS & 2SLS & OLS & 2SLS \\
\hline China's market share & $\begin{array}{c}-1.858^{* *} \\
(0.049)\end{array}$ & $\begin{array}{c}-3.816^{* *} \\
(0.178)\end{array}$ & $\begin{array}{l}-1.818^{* *} \\
(0.077)\end{array}$ & $\begin{array}{l}-4.440^{* *} \\
(0.371)\end{array}$ & $\begin{array}{c}-1.807^{* *} \\
(0.046)\end{array}$ & $\begin{array}{c}-3.815^{* *} \\
(0.179)\end{array}$ \\
\hline$\times$ time-sensitive & $\begin{array}{l}0.998^{* *} \\
(0.069)\end{array}$ & $\begin{array}{l}3.035^{* *} \\
(0.215)\end{array}$ & $\begin{array}{l}1.167^{* *} \\
(0.069)\end{array}$ & $\begin{array}{l}3.485^{* *} \\
(0.216)\end{array}$ & $\begin{array}{l}1.026^{* *} \\
(0.069)\end{array}$ & $\begin{array}{l}3.098^{* *} \\
(0.210)\end{array}$ \\
\hline$\times$ intermediate inputs & $\begin{array}{l}0.508^{* *} \\
(0.073)\end{array}$ & $\begin{array}{l}1.168^{* *} \\
(0.282)\end{array}$ & & & & \\
\hline$\times$ contract intensity & & & $\begin{array}{c}0.057 \\
(0.075)\end{array}$ & $\begin{array}{l}0.668^{*} \\
(0.303)\end{array}$ & & \\
\hline$\times$ skill intensity & & & & & $\begin{array}{l}0.570^{* *} \\
(0.089)\end{array}$ & $\begin{array}{l}1.137^{* *} \\
(0.290)\end{array}$ \\
\hline Observations & $1,628,298$ & $1,628,298$ & $1,628,298$ & $1,628,298$ & $1,628,298$ & $1,628,298$ \\
\hline N. clusters & 44,669 & 44,669 & 44,669 & 44,669 & 44,669 & 44,669 \\
\hline Kleibergen-Paap (F-stat) & & 145.0 & & 144.0 & & 315.3 \\
\hline
\end{tabular}

Note: Standard errors reported in parentheses are clustered at the product-destination level. Statistical significance: ${ }^{a}=p<0.1,{ }^{*}=p<0.05,{ }^{* *}=p<0.01$. All specifications include log import demand as a control variable (coefficients suppressed) as well as exporter-importer-HS6 and exporter-importer-year FEs. 
Table A4: China's impact on Bulgarian firm-level exports and time-sensitivity, 2001-2006

\begin{tabular}{|c|c|c|c|c|c|c|}
\hline \multirow{4}{*}{ Time-sensitivity measure: } & $(1)$ & 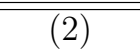 & 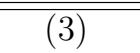 & $(4)$ & $(5)$ & (6) \\
\hline & \multicolumn{4}{|c|}{ Simple (broad) } & \multicolumn{2}{|c|}{ Adjusted (strict) } \\
\hline & \multirow{2}{*}{$\begin{array}{c}\text { Below } \\
\text { Median }\end{array}$} & \multirow{2}{*}{$\begin{array}{c}\text { Above } \\
\text { Median } \\
\text { OLS }\end{array}$} & \multicolumn{2}{|c|}{$\begin{array}{c}\text { Interaction: } \\
\text { Above first quartile }\end{array}$} & \multicolumn{2}{|c|}{$\begin{array}{c}\text { Interaction: } \\
\text { Above first quartile }\end{array}$} \\
\hline & & & OLS & 2SLS & OLS & 2SLS \\
\hline \multicolumn{7}{|c|}{ Dep. var.: $\log$ export revenues } \\
\hline China & $\begin{array}{l}-1.575^{*} \\
(0.652)\end{array}$ & $\begin{array}{l}-0.428 \\
(0.954)\end{array}$ & $\begin{array}{c}-0.462^{* *} \\
(0.174)\end{array}$ & $\begin{array}{c}-1.662^{* *} \\
(0.618)\end{array}$ & $\begin{array}{c}-0.508^{* *} \\
(0.174)\end{array}$ & $\begin{array}{c}-1.810^{* *} \\
(0.619)\end{array}$ \\
\hline China $\times$ time-sensitive & & & $\begin{array}{c}0.179 \\
(0.214)\end{array}$ & $\begin{array}{c}0.984 \\
(0.651)\end{array}$ & $\begin{array}{c}0.256 \\
(0.214)\end{array}$ & $\begin{array}{l}1.339^{*} \\
(0.658)\end{array}$ \\
\hline \multicolumn{7}{|c|}{ First stage results for China's expansion } \\
\hline$s_{n k t}^{C N} \times w_{j}$ & & & & $\begin{array}{l}1.750^{* *} \\
(0.185)\end{array}$ & & $\begin{array}{l}1.768^{* *} \\
(0.187)\end{array}$ \\
\hline$s_{n k t}^{C N} \times w_{j} \times$ High Quartile & & & & $\begin{array}{c}-0.686^{* *} \\
(0.208)\end{array}$ & & $\begin{array}{c}-0.715^{* *} \\
(0.209)\end{array}$ \\
\hline Observations & 137,070 & 129,414 & 268,822 & 268,822 & 268,822 & 268,822 \\
\hline N. Clusters & 7,262 & 8,379 & 15,738 & 15,738 & 15,738 & 15,738 \\
\hline Kleibergen-Paap (F-stat ) & & & & 71.8 & & 70.5 \\
\hline
\end{tabular}

Note: Standard errors reported in parentheses are clustered at the product-destination level. Statistical significance: ${ }^{a}=p<0.1,{ }^{*}=p<0.05,{ }^{* *}=p<0.01$. All specifications include destination-product, destination-year, and firm fixed effects. Log import demand and other firm-level control variables (Firm seniority, N. of Products, N. of Destinations) have been included in these specifications but coefficients are not reported in this Table. 


\section{B Estimating time-sensitivity}

In an attempt to measure differential time-sensitivity across product categories, Hummels and Schaur (2013) exploit detailed information on shipping mode in US trade data and estimate industry-specific markups firms are willing to pay to import a good via air freight instead of sea shipment. This markup informs about the value of fast delivery that is attributed to a particular good. Products for which the value of time is higher are considered as being relatively more time-sensitive. ${ }^{29}$ We argue that such goods should also reveal higher resilience towards Chinese competition in ESE exports, given their geographic proximity to EU15 destinations. To test this hypothesis, we use the data from Hummels and Schaur (2013) to replicate their methodology and to obtain a cross-sectional measure of time-sensitivity at the 2-digit HS sector level.

Model. Hummels and Schaur (2013) assume a simple demand function in which consumers purchase goods depending on its price, its quality, and the time it takes for delivery.

$$
q_{i}^{z}=E\left(\frac{p_{i}^{z *}}{v_{i}^{z} \exp \left(-\tau \cdot \text { days }_{i}^{m}\right)}\right)^{-\sigma}
$$

Given expenditure $E$, price $p_{i}^{z}$ and quality $v_{i}^{z}$ offered by a firm $z$ located in exporting country $i$ affect demand for its variety $q_{i}^{z}$. Besides this, the number of days it takes to ship a good from $i$ to the destination market negatively enters the demand function with an elasticity parameter $\tau$. Shipping times depend on the mode of transport $m$, which can be either ocean cargo $o$ or airfreight $a$. Since this model considers import demand by the US, there is no destination-specific subscript and the demand system is initially assumed to be the same across products.

On the supply side, firms $v$ face fixed costs $F$ of exporting and also charge differently, depending on the mode of transport. Shipping charges $g_{i}^{m}$ depend on the location of the exporter and the transport mode, where for any $i$ airfreight is more expensive than ocean cargo: $g_{i}^{a}>g_{i}^{o}$. With shipping charges being proportional to the quantity of a shipment (not its value), profits of the firm result as follows:

$$
\pi(z)_{i}^{m}=\frac{\left(z+g_{i}^{m}\right)}{\sigma-1} E\left(\frac{\left(z+g_{i}^{m}\right) / \theta}{v_{i}^{z} \exp \left(-\tau \cdot d a y s_{i}^{m}\right)}\right)^{-\sigma}-F
$$

Defining mode-specific ad-valorem shipping costs from exporter $i$ as $f_{i}^{m}=\left(1+g_{i}^{m} / p_{i}^{m}\right)$, and assuming that airfreight generally takes only one day to reach the destination, Hummels

\footnotetext{
${ }^{29}$ Hornok (2012) provides evidence that the European integration process has boosted trade in such timesensitive products disproportionately, as border waiting times and other trade barriers were dismantled.
} 
and Schaur (2013) derive the following relative export revenue equation for a firm $z$ shipping via air: ${ }^{30}$

$$
\ln \frac{r(z)_{i}^{a}}{r(z)_{i}^{o}}=\sigma \tau\left(\text { days }_{i}^{o}-1\right)+(1-\sigma) \ln \left(\frac{p_{i}^{a}}{p_{i}^{o}}\right)-\sigma \ln \left(\frac{f_{i}^{a}}{f_{i}^{o}}\right)+\sigma \ln \left(\frac{v_{i}^{a}}{v_{i}^{o}}\right)
$$

To take this specification to more aggregated data (i.e. product-level trade data), firmlevel revenues are multiplied by the number of $z_{i}^{m}$-type firms, $N_{i}^{m}$ :

$$
\ln \frac{R_{i}^{a}}{R_{i}^{o}}=\sigma \tau\left(\text { days }_{i}^{o}-1\right)+(1-\sigma) \ln \left(\frac{p_{i}^{a}}{p_{i}^{o}}\right)-\sigma \ln \left(\frac{f_{i}^{a}}{f_{i}^{o}}\right)+\sigma \ln \left(\frac{v_{i}^{a}}{v_{o}^{z}}\right)+\ln \left(\frac{N_{i}^{a}}{N_{i}^{o}}\right)
$$

Estimation. To estimate this equation, Hummels and Schaur (2013) exploit detailed US import data for the period 1991-2005, where they observe the exporting country $i$, 6-digit HS products $k$, arriving at coast $c=\{$ east, west $\}$, by mode $m$, at time $t$. The observable variables used for the estimation in our paper are the quantity of a shipment (in kilograms), the total value of a shipment (in US dollars), and shipping charges (in US dollars), so that we estimate the following regression equation:

$$
\ln \frac{X_{i k c t}^{a}}{X_{i k c t}^{o}}=\sigma \tau\left(\text { days }_{i c}^{o}-1\right)+(1-\sigma) \ln \left(\frac{u v_{i k c t}^{a}}{u v_{i k c t}^{o}}\right)-\sigma \ln \left(\frac{f_{i k c t}^{a}}{f_{i k c t}^{o}}\right)+\varepsilon_{i k c t}
$$

where $u v_{i k c t}^{m}$ denotes unit value of the shipment, to proxy prices, and $\varepsilon_{i k c t}=\sigma \ln \left(\frac{v_{i}^{a}}{v_{o}^{z}}\right)+$ $\ln \left(\frac{N_{i}^{a}}{N_{i}^{o}}\right)+\mu_{i k c t}$ denotes the error term. We estimate this model separately for each HS2 sector, including exporter-HS6 fixed effects. Our estimates of time-sensitivity are then computed by dividing the estimated $\hat{\sigma \tau}$ from the transit time variable in the equation by $\hat{\sigma}$ obtained from the relative freight-charges. As Hummels and Schaur (2013) also show for separate 5digit end-use categories in Appendix Figure A3, we obtain different estimates across sectors, where statistically significant estimates at the 10 percent level are strictly positive. ${ }^{31}$

In Figure B1 we present our estimates. In Panel (a), we display the distribution of timesensitivity estimates and highlight those observations that report statistically significant coefficients at the 10 percent level. They are strictly positive and range between 0 and 0.05 . In Panel (b) we set all insignificant estimates equal to zero, following the definition of our strict definition of time-sensitivity, and highlight the observations that range above median as we use the binary indicator for our regressions. The results in Panel (a) broadly resemble the pattern documented by Hummels and Schaur (2013, Fig.A3), who estimate individual

\footnotetext{
${ }^{30}$ Details of this derivation are shown in the online appendix, section A2.2, of their article.

${ }^{31}$ The data and code for running these regressions are provided in the supplementary materials to their original publication (https://www. aeaweb.org/articles?id=10.1257/aer.103.7.2935).
} 
coefficients for 5-digit end-use categories. Figure B2 shows that time-sensitive sectors also reveal a lower price elasticity of demand.

Figure B1: Distribution of time sensitivity across HS2 sectors

(a) Broad

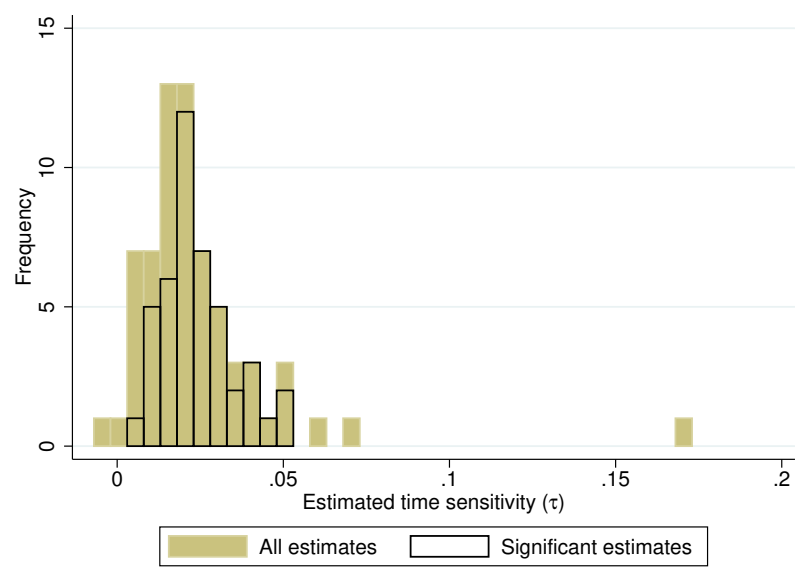

(b) Strict

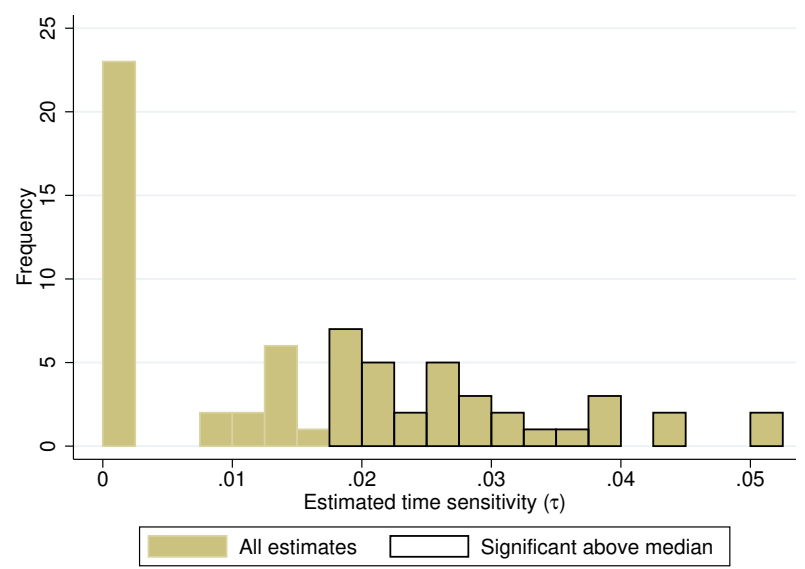

Note: Estimated time sensitivity using data and methodology from Hummels and Schaur (2013). Panel (a) baseline results (broad measure); panel (b) adjusted results (strict measure), after setting insignificant estimates equal zero. Sample restricted to manufacturing sectors, i.e. HS Chapters 28-96.

Figure B2: Correlation between time-sensitivity and the elasticity of substitution

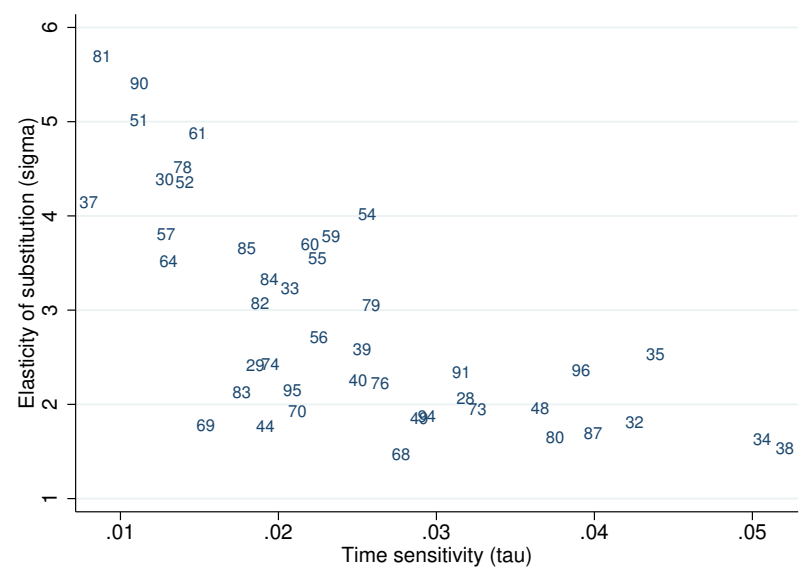

Note: Estimated time sensitivity and substitution elasticity using data and methodology from Hummels and Schaur (2013). Sample restricted to manufacturing sectors, i.e. HS Chapters 28-96, with statistical significance of 10 percent or higher. 
Table B1: Examples of time-sensitive and time-insensitive industries, strict measure

\begin{tabular}{|c|c|c|c|}
\hline \multicolumn{4}{|c|}{ Most time-sensitive (top 5) } \\
\hline HS Section & Section name & HS2 Chapter & Chapter description \\
\hline VI & Chemicals and allied industries & 38 & Chemical products n.e.c. \\
\hline VI & Chemicals and allied industries & 34 & $\begin{array}{l}\text { Soap, Organic surface-active agents; Washing, lubricat- } \\
\text { ing, polishing or scouring preparations; Artificial or pre- } \\
\text { pared waxes, Candles and similar articles, Modelling } \\
\text { pastes, Dental waxes and dental preparations with a ba- } \\
\text { sis of plaster }\end{array}$ \\
\hline VI & Chemicals and allied industries & 35 & $\begin{array}{l}\text { Albuminoidal substances; Modified starches; Glues; En- } \\
\text { zymes }\end{array}$ \\
\hline VI & Chemicals and allied industries & 32 & $\begin{array}{l}\text { Tanning or dyeing extracts; Tannins and their deriva- } \\
\text { tives; Dyes, pigments and other colouring matter; } \\
\text { Paints, varnishes; Putty, other mastics; Inks }\end{array}$ \\
\hline XVII & Vehicles, Aircraft, Vessels & 87 & $\begin{array}{l}\text { Vehicles; Other than railway or tramway rolling stock, } \\
\text { and parts and accessories thereof }\end{array}$ \\
\hline \multicolumn{4}{|c|}{ Least time-sensitive (bottom 5 ) } \\
\hline HS Section & Section name & HS2 Chapter & Chapter description \\
\hline VI & Chemicals and allied industries & 36 & $\begin{array}{l}\text { Explosives; Pyrotechnic products; Matches; Pyrophoric } \\
\text { alloys; Certain combustible preparations }\end{array}$ \\
\hline $\mathrm{X}$ & Wood and wood products & 47 & $\begin{array}{l}\text { Pulp of wood or other fibrous cellulosic material; Recov- } \\
\text { ered (waste and scrap) paper or paperboard }\end{array}$ \\
\hline VIII & Hides and Skins, Leather, Furskins & 41 & Raw hides and skins (other than furskins) and leather \\
\hline $\mathrm{XIV}$ & Pearls, Precious stones and metals & 71 & $\begin{array}{l}\text { Natural, cultured pearls; Precious, semi-precious stones; } \\
\text { Precious metals; Metals clad with precious metal, and } \\
\text { articles thereof; Imitation jewellery; Coin }\end{array}$ \\
\hline $\mathrm{XI}$ & Textiles and textile products & 50 & Silk \\
\hline
\end{tabular}

Note: Authors' compilation. Section and chapter descriptions based on information from Foreign Trade Online (https://www.foreign-trade.com/reference/hscode.htm). 


\section{Heterogeneous effects across exporters}

\section{C.1 Differential effects across countries}

Our sample encompasses exporting countries at different stages of economic development, as a consequence we might expect differential responses to Chinese competition across these countries. In particular, assuming that Chinese exports partly expand due to lower relative prices, the level of economic development and the average price level of exports across ESE countries could play a role in determining exposure to Chinese competition.

Exporter and country-pair specific coefficients. We first check whether our results are generally driven by individual exporting countries. To evaluate this, we add an additional term into our specification which interacts our main variable of interest with an exporterspecific dummy variable:

$$
\ln X_{i j k t}=\alpha+\beta s_{j k t}^{C N}+\beta_{i}\left(s_{j k t}^{C N} \times \mathbf{D}_{i}\right)+\gamma \ln M_{j k t}+\mu_{i j k}+\mu_{i j t}+\nu_{i j k t},
$$

The estimate of $\beta_{i}$ will inform about the differential effect of Chinese export market competition on country $i$, relative to other ESE exporters. Furthermore, $\left(\hat{\beta}+\hat{\beta}_{i}\right)$ will inform us about the overall magnitude of the displacement of $i$ 's exports. We summarize OLS estimates of Equation (C.1) graphically in Figure C1. The vertical axis denotes the magnitude of the point estimate for Chinese competition and the solid horizontal line, surrounded by the shaded area, denotes the displacement effect and 95-percent confidence interval we obtained from our baseline specification in Table 2, column (1). Red dots and vertical lines denote

the estimated base-effect, $\hat{\beta}$, obtained from Equation (C.1). The blue dots and vertical lines denote the respective effect estimated for the individual exporter, $\left(\hat{\beta}+\hat{\beta}_{i}\right)$. 
Figure C1: Exporter specific displacement effects versus baseline

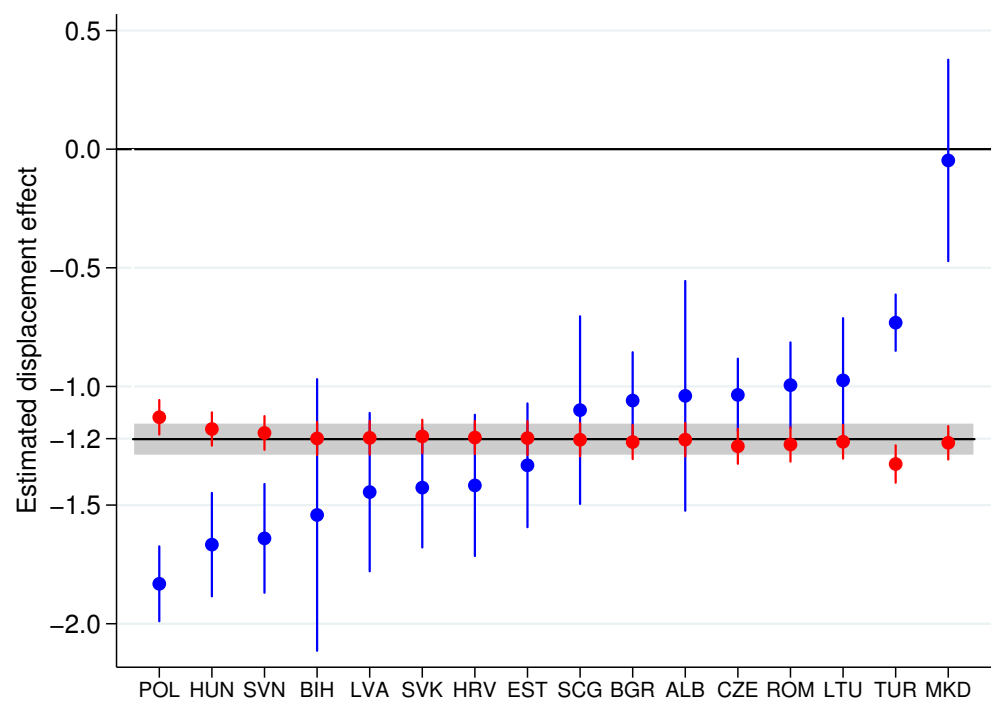

Note: Author's calculations. Shaded area with solid line: baseline result from Eq. (1). From Eq. (C.1): red - base-effect $(\hat{\beta})$; blue - individual effect $\left(\hat{\beta}+\hat{\beta}_{i}\right)$; vertical lines - 95-percent confidence intervals.

Comparing the base effects reported in Figure $\mathrm{C} 1$, we find that no single exporting country in our sample drives our baseline result. If this were the case, we would have seen that red dots and confidence intervals do not overlap with the grey area. Only for two exporters (Poland and Turkey), point estimates reside just outside this area. Turning to the exporter-specific coefficients, indicated by the blue points, we find that some exporters do reveal differential responses. At one end of this spectrum, this concerns countries with significantly stronger displacement effects, such as Poland, Hungary and Slovenia. At the other extreme, Turkey and Northern Macedonia are significantly less affected than the rest of the ESE countries in our sample. Northern Macedonia, with a point estimate just below zero, appears to be entirely unaffected by Chinese competition. For the rest of our exporters we observe point estimates ranging fairly close to our baseline results, i.e. from slightly above -1.0 to slightly below -1.5 . Some of them reveal differential effects at the 10 percent level of statistical significance, such as Bulgaria, for which $\hat{\beta}_{i}=0.175$ suggests an about 14 percent smaller displacement effect compared to the rest of the sample. 
Figure C2: Country-pair specific displacement effects; distribution of interaction coefficients

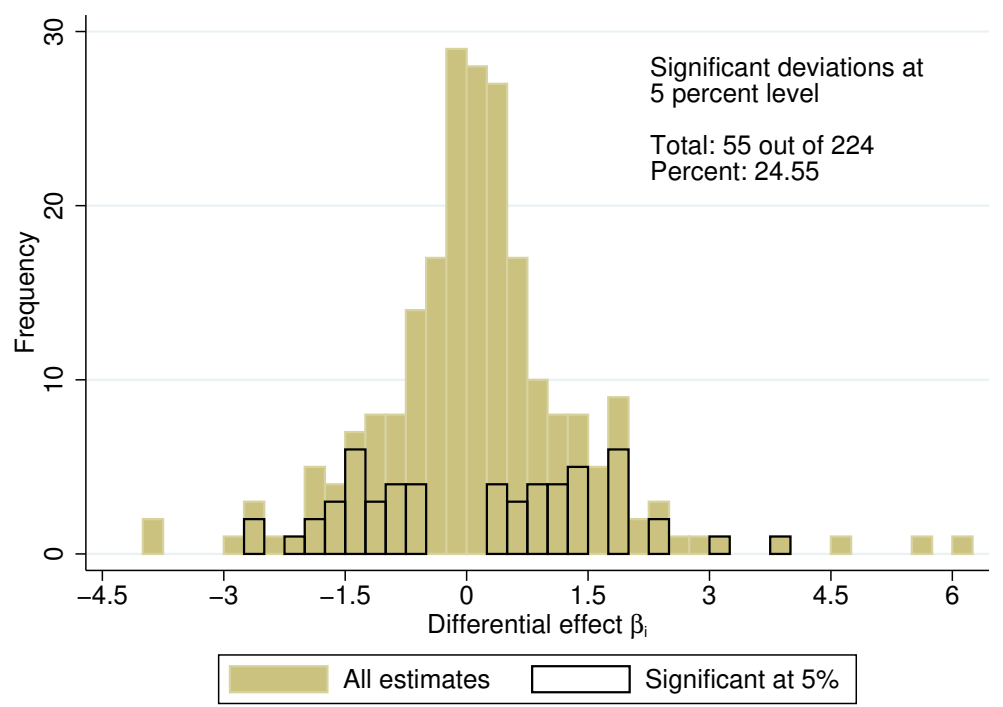

Note: Author's calculations based on 224 regressions for individual country-pair effects of Chinese competition on ESE exports. Histogram shows frequency of $\hat{\beta}_{i j}$ magnitudes. Lined bars denote frequency of significant deviations from base-effect at 5 percent level.

Exploring these dimensions further, we also estimated separate coefficients for each exporter-importer pair $i j{ }^{32}$ The overall distribution of estimated interaction coefficients, $\hat{\beta}_{i j}$, is displayed in Figure C2. For about three out of four country pairs, we find no statistically significant difference from the baseline effect. The remaining pairs indicate either larger or smaller displacement, with interaction coefficients $\hat{\beta}_{i j}=[-3,3]$. Looking at individual $i j$-pairs in Figure C3, we observe that the less exposed exporters identified above (Turkey and Northern Macedonia) reveal significant deviations in about 50 percent of the EU15 destinations. On the importer side, we find frequent cases of systematically smaller displacement in the United Kingdom and Italy, while displacement tends to be more pronounced in Sweden, France, Austria and Germany. We cannot infer any obvious systematic relation to importing country characteristics, but we explore those across exporters in the following subsection.

EEC vs SEE and exporter characteristics. In Table C1, Panel A, we present OLS results for alternative exporter specific interaction terms with our main variable of interest. ${ }^{33}$

\footnotetext{
${ }^{32}$ With 14 importers and 16 exporters, we ran 224 regressions to obtain indication for differential effects in all possible combinations.

${ }^{33}$ Information about the data sources and construction of interaction variables are provided in the footnote of Table C1.
} 
Figure C3: Differential effects of Chinese competition for individual country pairs

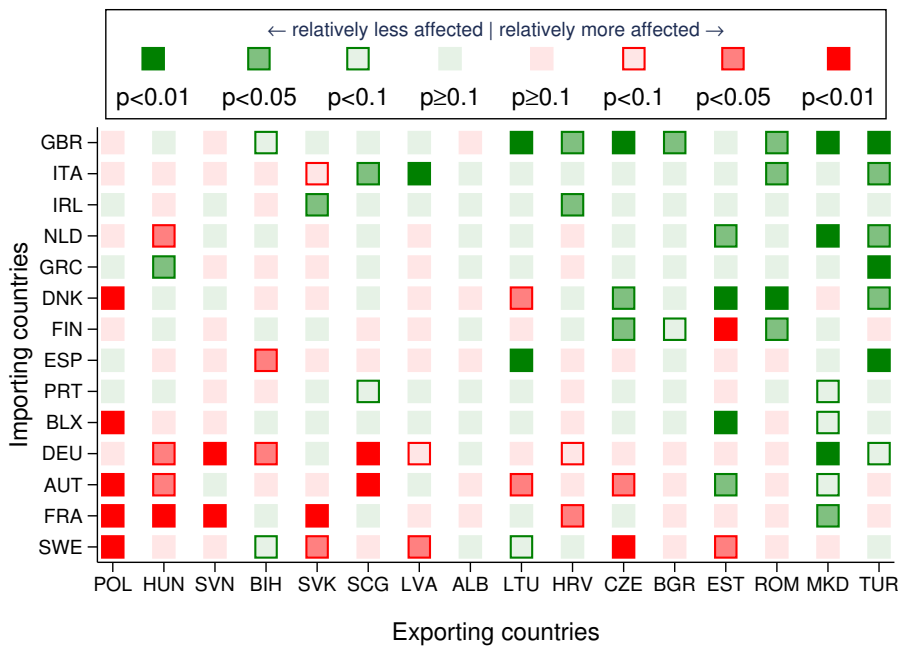

Note: Author's calculations based on repeated estimates of baseline product-level OLS specification with respective country-pair interaction. Positive coefficients (suggesting weaker responses) are colored in green, whereas negative coefficients (suggesting stronger responses) are colored in red. The intensity of the colors indicates different levels of statistical significance (see legend).

We begin with a simple dummy variable for the eight Eastern European countries (EEC), which became full EU members in 2004. This country group appears to face systematically larger displacement effects of Chinese competition. In column (2) we use another measure that captures exporters' relative stage in the EU integration process, measuring the fraction of HS6 product lines exported to the EU15 free of tariffs at the beginning of our sample period (1997-1999). We find again a negative and significant interaction coefficient. In column (3)-(4) we confirm our previous conjecture that countries at higher stages of economic development and with higher price levels are differently affected by Chinese competition.

We also check whether ESE exporters receiving higher inflows of FDI (measured in percent of GDP) reveal different effects. This seems to be the case if we include FDI individually, in column (5), but the sign and magnitude becomes ambiguous in columns (6) and (7). Overall, results suggest that exporters at more advanced stages of the EU integration process, and those with higher price levels of output experience systematically larger reductions in their export revenues. Economically more advanced countries appear to be less affected, after controlling for prices, trade integration with the EU and FDI inflows. ${ }^{34}$

In the lower Panel of Table C1, we revisit these results with a restricted sample that excludes Turkey from our control group. The reasons for doing so are twofold: (i) Turkey

\footnotetext{
${ }^{34}$ In Figure C4, we show differences and commonalities between EEC and SEE exporters in terms of the country characteristics we take into consideration.
} 
appeared to potentially bias our baseline estimates upwards, as it reveled to be systematically less affected by Chinese competition, while accounting for a large portion of our observations (about 13.4 percent); (ii) this relative resilience might be due to a number of unobserved characteristics, which make Turkey different from the rest of our ESE exporters. For instance, it was never part of the former Eastern Bloc of Socialist economies and it was also subject to different EU integration policies after the breakdown of the Soviet Union. Hence, excluding Turkey from our sample will help us understanding to what extent findings in Panel A are driven by a single potential outlier in our database.

In columns (1) and (2) of Table C1, we observe that the differential effect for early integrating economies is indeed smaller once we exclude Turkey from the sample. Instead of 57 percent, Panel B suggests only 37 percent larger displacement of EEC relative to SEE exporters. The relative magnitudes of interaction coefficients in columns (3) and (4) also reveal some changes. More interestingly, however, column (5) suggests that higher FDI inflows into the exporting countries are associated with significantly smaller displacement effects, which is the opposite of what we found in Panel A. This relationship remains robust across all our alternative specifications that exclude Turkey from our sample and suggests that FDI inflows may have contributed to higher competitiveness of ESE exporters vis-à-vis China. In our full specifications, reported in columns (6) and (7) of Panel B, we confirm our previous findings that higher prices undermine competitiveness while higher stages of economic development contribute to relatively higher resilience. ${ }^{35}$ The last column of our table further suggests that EEC countries are no longer systematically more affected, once we control for more specific exporter characteristics. Early trade integration, as measured by the fraction of tariff free product lines, however, remains significant. We interpret this correlation as indicative for a EU integration process that contributed to economic restructuring and favored larger displacement by Chinese exports.

\footnotetext{
${ }^{35}$ An explanation for the latter result could be that more advanced economies export different varieties of a good that compete less with Chinese varieties in a destination. This would be in line with the literature on relative export quality which influences the elasticity of substitution derived from prices (e.g. Schott, 2008).
} 
Table C1: Differential impact of China across ESE exporters, product-level data, 1997-2007

\begin{tabular}{|c|c|c|c|c|c|c|c|}
\hline \multirow[b]{2}{*}{ Dep. var.: log export revenue } & $\overline{(1)}$ & $\overline{(2)}$ & 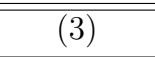 & $(4)$ & 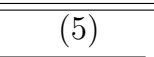 & 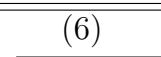 & $(7)$ \\
\hline & \multicolumn{5}{|c|}{ Individual interactions } & \multicolumn{2}{|c|}{ Combined } \\
\hline \multicolumn{8}{|c|}{ Panel A: Full sample - 16 ESE exporters } \\
\hline China $\left(s_{j k t}^{C N}\right)$ & $\begin{array}{c}-0.919^{* *} \\
(0.046)\end{array}$ & $\begin{array}{c}-0.757^{* *} \\
(0.068)\end{array}$ & $\begin{array}{c}-0.953^{* *} \\
(0.102)\end{array}$ & $\begin{array}{c}-1.029^{* *} \\
(0.059)\end{array}$ & $\begin{array}{c}-1.221^{* *} \\
(0.036)\end{array}$ & $\begin{array}{c}-0.913^{* *} \\
(0.107)\end{array}$ & $\begin{array}{c}-1.059^{* *} \\
(0.112)\end{array}$ \\
\hline$\times \mathrm{EEC}_{i}$ & $\begin{array}{c}-0.525^{* *} \\
(0.057)\end{array}$ & & & & & & $\begin{array}{c}-0.472^{* *} \\
(0.103)\end{array}$ \\
\hline$\times$ Free $\mathrm{HS}_{i}$ & & $\begin{array}{c}-0.726^{* *} \\
(0.097)\end{array}$ & & & & $\begin{array}{c}-1.132^{* *} \\
(0.140)\end{array}$ & $\begin{array}{c}-0.679^{* *} \\
(0.171)\end{array}$ \\
\hline$\times(\log ) \mathrm{GDPpc}_{i}$ & & & $\begin{array}{c}-0.225^{* *} \\
(0.081)\end{array}$ & & & $\begin{array}{l}0.612^{* *} \\
(0.117)\end{array}$ & $\begin{array}{l}0.606^{* *} \\
(0.117)\end{array}$ \\
\hline$\times(\log )$ Price-level $_{i}$ & & & & $\begin{array}{c}-0.398^{* *} \\
(0.099)\end{array}$ & & $\begin{array}{c}-0.650^{* *} \\
(0.128)\end{array}$ & $\begin{array}{c}-0.370^{* *} \\
(0.143)\end{array}$ \\
\hline$\times$ FDI inflow $i$ & & & & & $\begin{array}{c}-0.073^{* *} \\
(0.025)\end{array}$ & $\begin{array}{l}-0.006 \\
(0.033)\end{array}$ & $\begin{array}{c}0.059 \\
(0.037)\end{array}$ \\
\hline Observations & $1,628,298$ & $1,628,298$ & $1,628,298$ & $1,628,298$ & $1,628,298$ & $1,628,298$ & $1,628,298$ \\
\hline N. Clusters & 44,669 & 44,669 & 44,669 & 44,669 & 44,669 & 44,669 & 44,669 \\
\hline \multicolumn{8}{|c|}{ Panel B: Restricted sample - 15 ESE exporters (excl. Turkey) } \\
\hline China $\left(s_{j k t}^{C N}\right)$ & $\begin{array}{r}-1.052^{* *} \\
(0.063)\end{array}$ & $\begin{array}{c}-0.964^{* *} \\
(0.082)\end{array}$ & $\begin{array}{c}-1.068^{* *} \\
(0.104)\end{array}$ & $\begin{array}{c}-1.057^{* *} \\
(0.059)\end{array}$ & $\begin{array}{c}-1.363^{* *} \\
(0.042)\end{array}$ & $\begin{array}{c}-0.884^{* *} \\
(0.106)\end{array}$ & $\begin{array}{c}-0.942^{* *} \\
(0.113)\end{array}$ \\
\hline$\times \mathrm{EEC}_{i}$ & $\begin{array}{c}-0.391^{* *} \\
(0.069)\end{array}$ & & & & & & $\begin{array}{l}-0.177 \\
(0.120)\end{array}$ \\
\hline$\times$ Free $\mathrm{HS}_{i}$ & & $\begin{array}{c}-0.521^{* *} \\
(0.105)\end{array}$ & & & & $\begin{array}{c}-0.925^{* *} \\
(0.144)\end{array}$ & $\begin{array}{c}-0.781^{* *} \\
(0.171)\end{array}$ \\
\hline$\times(\log ) \mathrm{GDPpc}_{i}$ & & & $\begin{array}{c}-0.215^{* *} \\
(0.081)\end{array}$ & & & $\begin{array}{l}0.302^{*} \\
(0.125)\end{array}$ & $\begin{array}{l}0.337^{* *} \\
(0.128)\end{array}$ \\
\hline$\times(\log )$ Price-level $_{i}$ & & & & $\begin{array}{c}-0.584^{* *} \\
(0.103)\end{array}$ & & $\begin{array}{c}-0.474^{* *} \\
(0.130)\end{array}$ & $\begin{array}{c}-0.391^{* *} \\
(0.143)\end{array}$ \\
\hline$\times$ FDI inflow $i$ & & & & & $\begin{array}{l}0.110^{* *} \\
(0.035)\end{array}$ & $\begin{array}{l}0.164^{* *} \\
(0.042)\end{array}$ & $\begin{array}{l}0.168^{* *} \\
(0.042)\end{array}$ \\
\hline Observations & $1,409,858$ & $1,409,858$ & $1,409,858$ & $1,409,858$ & $1,409,858$ & $1,409,858$ & $1,409,858$ \\
\hline N. Clusters & 42,913 & 42,913 & 42,913 & 42,913 & 42,913 & 42,913 & 42,913 \\
\hline
\end{tabular}

Note: Results reflect OLS estimates. Standard errors in parentheses clustered at product-destination level. Statistical significance: ${ }^{a} p<0.1,{ }^{*} p<0.05,{ }^{* *} p<0.01$. All specifications include exporter-importerproduct $\mathrm{FE}$, exporter-importer-year $\mathrm{FE}$ and $\log$ import demand as controls. $\mathrm{EEC}_{i}$ is a dummy variable for 8 ESE exporters becoming EU members in 2004; Free ${ }_{i}$ measures trade integration with the EU15 by the

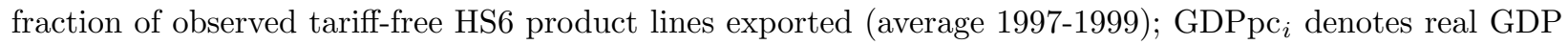
per capita relative to China (output-based measure, in chained PPPs, as reported in PWT 9.0; average 1995-1997). Price-level ${ }_{i}$ denotes price levels of output relative to China (as reported in PWT 9.0; average 1995-1997); FDI inflow $i$ in percent of GDP, normalized to mean zero and standard deviation of one (original from WDI database, average 1998-2001). 
Figure C4: Eastern vs Southeast European exporters

(a) Fraction tariff-free

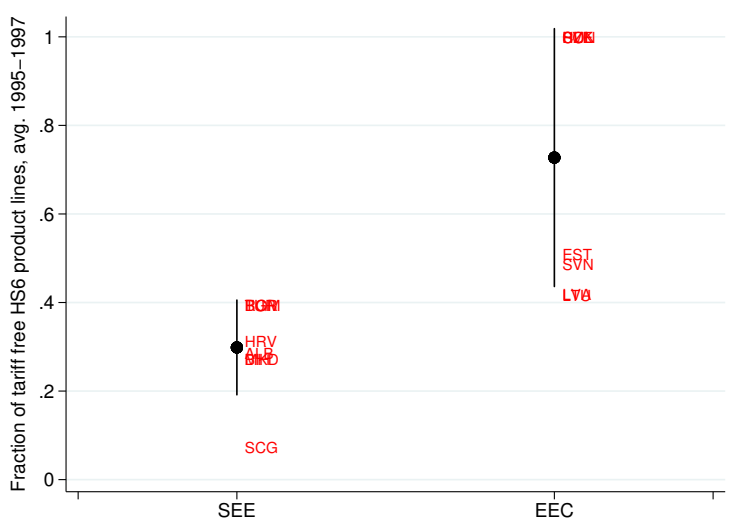

(c) Price level of GDP

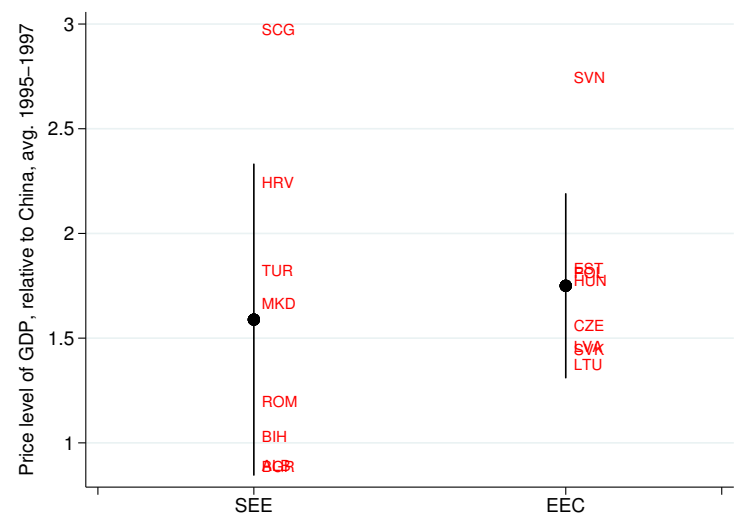

(b) Real GDP per capita

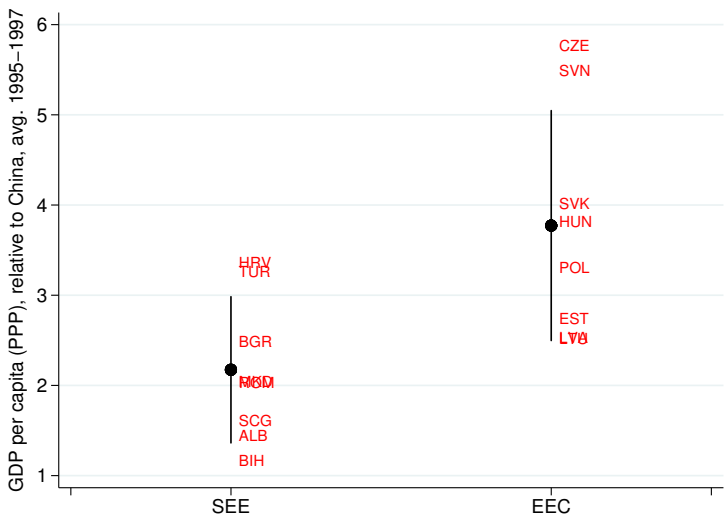

(d) FDI inflows

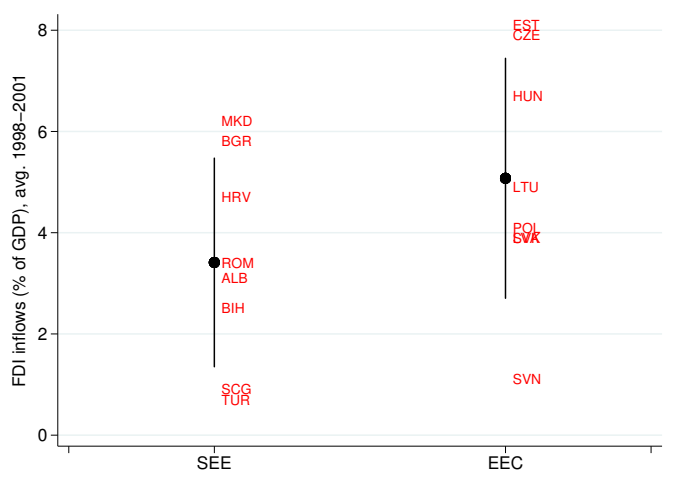

Note: Tariff information based on data from World Integrated Trade Solutions (WITS). Data for real GDP and price level of GDP from Penn World Tables 9.0. FDI inflow figures based on data from the World Development Indicators database. 


\section{C.2 Differential effects across firms}

Multi-product and multi-destination firms. The theoretical and empirical literature gives mixed suggestions for a differential impact of Chinese competition on larger firms. While multi-product or multi-destination firms might be assumed to be bigger and more productive, thus less affected, the opposite effect is also possible. In particular, Holmes and Stevens (2014) document patterns suggesting that larger firms are more exposed to Chinese competition and, hence are more affected. The reason is that larger firms have more standardized production processes and focus more on large-scale consumption varieties than smaller firms that are flexible to customize their production. While such patterns have been documented for US data, it is questionable whether this would be confirmed as well for Bulgaria. We first assess whether introducing a different proxy for firm size changes our findings. We build a variable for large firms which defines a firm as large if it reports revenues above the $75^{t} h$ percentile of firm-level export revenue in the first year in which it starts exporting. This variable is constant for the following years in which the firm is present in our database. OLS and 2SLS regressions reported in Table C2, show that large firms are significantly less affected by Chinese competition. Relying on OLS estimates we observe that large firms are 50 percent less affected by Chinese competition.

We then analyze the differential impact of Chinese competition across firm types by classifying multi-product firms as those selling several HS6 products in the same year to any EU15 destination. Likewise, we define multi-destination firms as those exporting the same HS6 product to at least two destination countries in a given year. In both cases we use the first observation available for a firm so that its status as a multi-product or multi-destination firm is time-invariant. Evidence shows that multi-destination firms are less harmed by Chinese competition in the various destination markets. The result in column (3) is confirmed by a corresponding IV estimate in column (4). On the contrary, estimates on multi-product firms show that the impact of Chinese competition does not differently affect the performance of these firms. Moreover, the impact of Chinese competition on firms exporting only one product across different destinations does not appear to be statistically significant. Chinese competition has a negative impact on exporters selling their products to only one destination rather than on exporters supplying only one product. 
Table C2: Heterogeneous effects on Bulgarian, large, multi-destination and multi-product firms

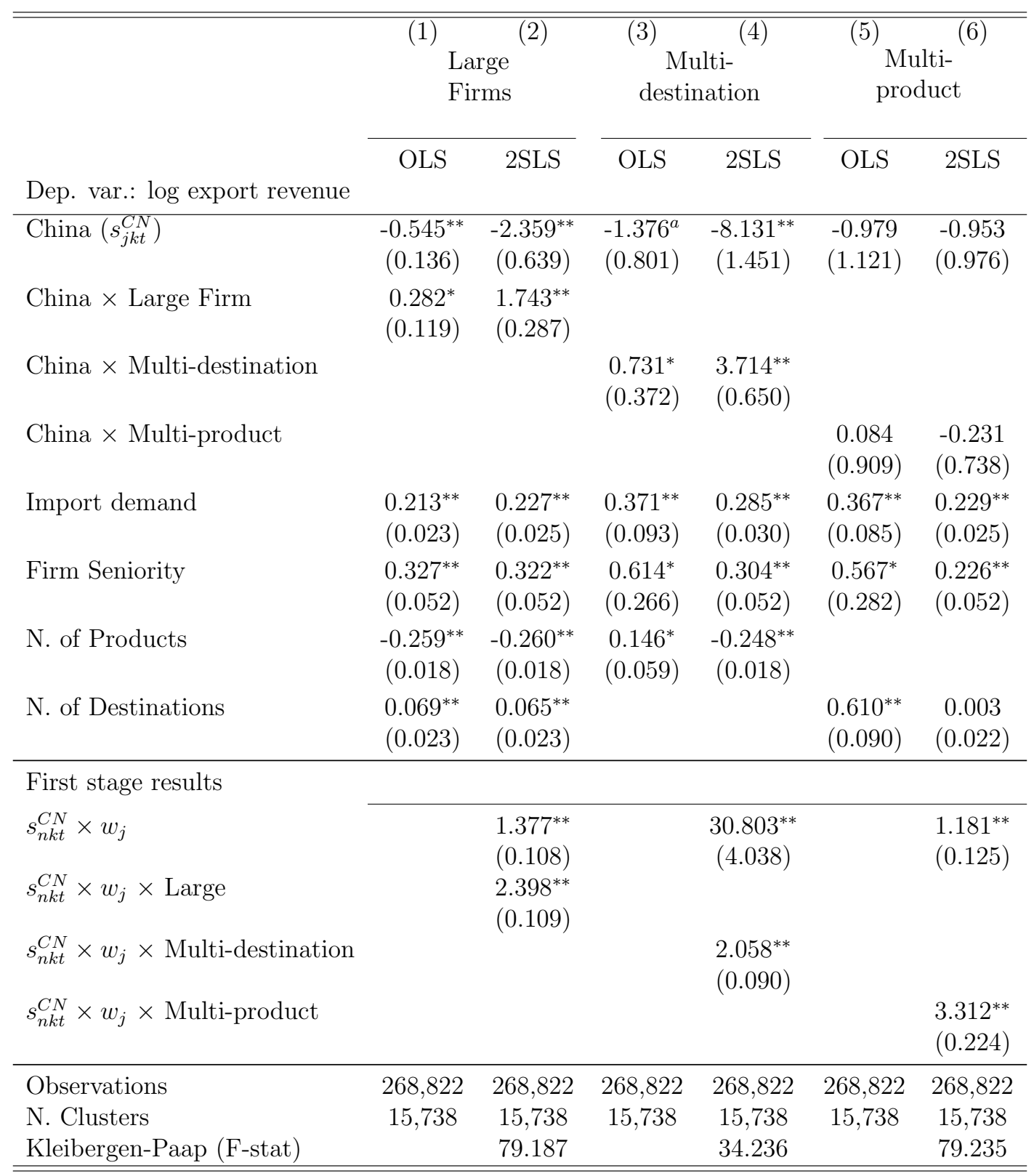

Note: Standard errors reported in parentheses are clustered at the product-destination level. Statistical significance: ${ }^{a}=p<0.1,{ }^{*}=p<0.05,{ }^{* *}=p<0.01$. All specifications include destination-product, destination-year, and firm fixed effects. Regression (3) and (5) employ weighted OLS, export quantities used as probability weights. For those specifications including two instrumental variables we report first stage estimates only for the instrumented variable of interest. 